\title{
GIS-Hydrogeochemical Model of the Yaoundé Fractured Rock Aquifer, Cameroon: Aquifer Setting, Seasonal Variations in Groundwater-Rock Interaction and Water Quality
}

\author{
Richard Ayuk II Akoachere ${ }^{*}{ }^{(0)}$, Omabgemi Omoloju Yaya ${ }^{2}$, Sonia Ebot Egbe1, \\ Thomson Areakpoh Eyong1, Bihmimihney Nelly Nji', Diana Besem Tambe ${ }^{3}$ \\ ${ }^{1}$ Department of Geology, University of Buea, Buea, Cameroon \\ ${ }^{2}$ National Water Resources Institute, Kaduna, Nigeria \\ ${ }^{3}$ Advanced School of Public Works, Yaoundé, Cameroon \\ Email: *r.akoachere@ubuea.cm
}

How to cite this paper: Akoachere, R. A. II, Yaya, O. O., Egbe, S. E., Eyong, T. A., Nji, B. N., \& Tambe, D. B. (2019). GIS-Hydrogeochemical Model of the Yaoundé Fractured Rock Aquifer, Cameroon: Aquifer Setting, Seasonal Variations in Groundwater-Rock Interaction and Water Quality. Journal of Geoscience and Environment Protection, 7, 232-263.

https://doi.org/10.4236/gep.2019.75018

Received: March 12, 2019

Accepted: May 27, 2019

Published: May 30, 2019

Copyright $\odot 2019$ by author(s) and Scientific Research Publishing Inc. This work is licensed under the Creative Commons Attribution International License (CC BY 4.0).

http://creativecommons.org/licenses/by/4.0/

\section{(c) (i) Open Access}

\begin{abstract}
This study of the gneiss-fractured-rock aquifer in Yaoundé capital of Cameroon determines: the aquifer setting-flow systems, the aquifer type, seasonal variations in rock-water interactions, evolution of the hydrogeochemical processes, physicochemical parameters and the suitability for domestic-agro-industrial use of the groundwater. Physicochemical field tests were carried out on 445 wells during four seasons for EC, $\mathrm{pH}$, TDS, Temperature and static water level from July 2016 to May 2017. 90 well samples were analyzed 45 samples per season: wet/dry. 38 borewell logs were used together with structural data to determine the aquifer setting. The field physico-chemical and laboratory analysis data of well samples were mounted unto various GIS software platforms: Global mapper, AqQa, Aquachem, Rockworks, Logplot7, Surfer and ArcGIS, to get indices/parameters/figures, by use of Durov's, Piper's and Gibbs diagrams, Water quality index WQI, USSL ratio, Sodium Absorption ratio SAR, Percent sodium \%Na, Kelly Ratio KR, Magnesium Absorption Ratio MAR, Total Hardness TH, Residual Sodium Carbonate RSC and Permeability Index PI that were determined. The process of groundwater ions acquisition is three-fold: by recharge through atmospheric precipitation, by ion exchange/simple dissolution between the rock-groundwater and by groundwater mixing in its flow path. Water types are $\mathrm{Ca}-\mathrm{HCO}_{3}, \mathrm{Mg}-\mathrm{HCO}_{3}$ and $\mathrm{Mg}-\mathrm{Cl}$ while hydrogeochemical facies are $\mathrm{Ca}-\mathrm{Mg}-\mathrm{HCO}_{3}$ and $\mathrm{Ca}-\mathrm{Mg}-\mathrm{Cl}-\mathrm{SO}_{4}$. Most water samples are fresh, potable and soft all seasons. The hydrogeologi-
\end{abstract}


cal conceptual model is that of a three-layered single phreatic fractured-rock-aquifer while other researchers postulated a two-aquifer, phreatic and semi-confined, two-layered model.

\section{Keywords}

GIS-Hydrogeochemical Model, Groundwater-Rock Interaction, Fractured Rock Aquifer, Aquifer Setting, Water Quality, Yaoundé, Cameroon

\section{Introduction}

Yaoundé city, Mfoundi division in the Centre Province is the capital city of Cameroon. The main activities carried out in the study area seat of all ministerial head offices are mostly the business of government, industrial activities and small scale agriculture. Yaoundé has a typical Classic equatorial Guinean climate which is tropically wet and dry with a regular and abundant precipitation (1600 mm per day), an average annual air temperature of approximately $24^{\circ} \mathrm{C}$ and an evaporation of about $800 \mathrm{~mm}$ per year (Fouepe et al. 2011). This climate is characterized by four seasons: eight months of rainy season, from mid-August to mid-November and four months of dry season from mid-November to February. The climate also has a short rainy season from March-June and a short dry season from July-August.

Yaoundé's population is 3.066 million with a growth rate between $6 \%$ and $8 \%$ per annum (United States Central Intelligence Agency, 2018). This growth rate far exceeds the rate of development of infrastructure. As such, the government is left with a fire-brigade-reflex of pre-planned new-layouts and lots in response to housing; hoping other services will follow later. This results in chaotic urbanization which makes the development of water supply infrastructure problematic.

In Cameroon, pipe-borne water supply systems are presently catering for the needs of less than $50 \%$ of cities and towns. In Yaoundé, less than $30 \%$ of households have direct access to drinking water. This rate falls to less than $20 \%$ for households that have access to the drinking water network in sub-urban centers with $<100,000$ inhabitants and since the supply is erratic, most people will at some point use either wells, springs or rivers (Fouepe et al., 2011; Nola et al., 1998; Djeuda et al., 1999; Tanawa et al., 2002).

Dugwells are the most popular source of groundwater in villages and towns in Cameroon. Classifying the sources of groundwater by uses in order of importance in Yaoundé is as follows: dugwells $80 \%>$ springs $6 \%>$ borewells $4 \%$. This is due to the fact that dugwells are easier to construct, need less complex technical skills, are cheaper and as such more cosmopolitan. Every house has one where possible. In Yaoundé where there are over 3000 dugwells, there are three dugwells in one household at Melen quarters, each belonging to one of three feuding brothers.

In Cameroon, sedimentary basins make up less than $20 \%$ of the land surface. 
As such, over $80 \%$ of the aquifers systems are fractured rock aquifers of igneous and metamorphic origin. There are however very few studies on the fractured rock aquifer systems in Cameroon.

The future development and expansion of Yaoundé as a capital city might depend on whether or not there is availability of water in quantity and in quality for use by the population. The Yaoundé fractured rock aquifer is therefore of great interest. Potable water is an existentially essential resource. There is a critical need for a complete understanding of the hydrogeology of the capital city Yaoundé. Also, the absence of proactive water management tools for planning an integrated hydrogeological approach to understanding the hydrogeology of Yaoundé begs our attention. The development of the full potential of this fractured rock aquifer depends on its systems/structural styles, an understanding of the rock/groundwater interaction, hydrogeochemical evolution, and the groundwater quality status for all uses and these must be part of the solution to satisfying the water needs of Yaoundé and other major fractured rock aquiferous formations in Cameroon.

Groundwater is a critical resource for people and ecosystems and tools are needed for efficient data management so that more technically sound and community-supported decisions may be made (Rossetto et al., 2018). This informed our decision to carry out this study to provide tools such as; chemical parameters and indices from analysis, interpretation of field data and the proposal of a good conceptual model of the aquiferous formations in Yaoundé.

Although a comprehensive hydrogeological investigation has not been made heretofore of the whole city of Yaoundé, many researchers have carried out works on selected groundwater topics and in parts of Yaoundé. Notable amongst them are: Flow dynamics of lineaments in Yaoundé (Teikeu et al., 2016); mass balance of Nitrogen and Potassium in parts of Yaoundé (Kringel et al., 2016); assessment of groundwater quality for domestic and irrigation purposes in parts of Yaoundé (Tabue et al., 2012); use of geoelectric tools to explore the lithostratigraphy of the aquiferous formations in parts of Yaoundé (Teikeu et al., 2012); assessment of bacterial contamination in the Mfoundi Watershed (Kuitcha et al., 2010) and modeling of groundwater flow in Yaoundé IV district (Fouepe et al., 2011).

This study of the whole city of Yaoundé aimed at giving an in-depth into the hydrogeology of Yaoundé describes work on; the aquifer flow systems, hydrogeochemical processes in groundwater/rock interaction, a new conceptual model of the aquifer system(s), the seasonal variations in groundwater physico-chemical parameters and groundwater chemical quality all of which have not been dealt with in-depth by the other researchers; is situated between longitudes $11.42^{\circ} \mathrm{E}$ to $11.56^{\circ} \mathrm{E}$ and latitudes $3.78^{\circ}$ to $3.92^{\circ} \mathrm{N}$ with elevations of $550-772 \mathrm{~m}$. a.m.s.l (meters above mean sea level) covering an area of $(12.41 \mathrm{Km} \times 17.12 \mathrm{Km}) 212.46 \mathrm{Km}^{2}$.

\section{Hydrology, Geology and Hydrogeology}

Yaoundé city is drained by the Mfoundi River and its many tributaries. The stream and river network is dense and dendritic Figure 1. The Yaoundé series 


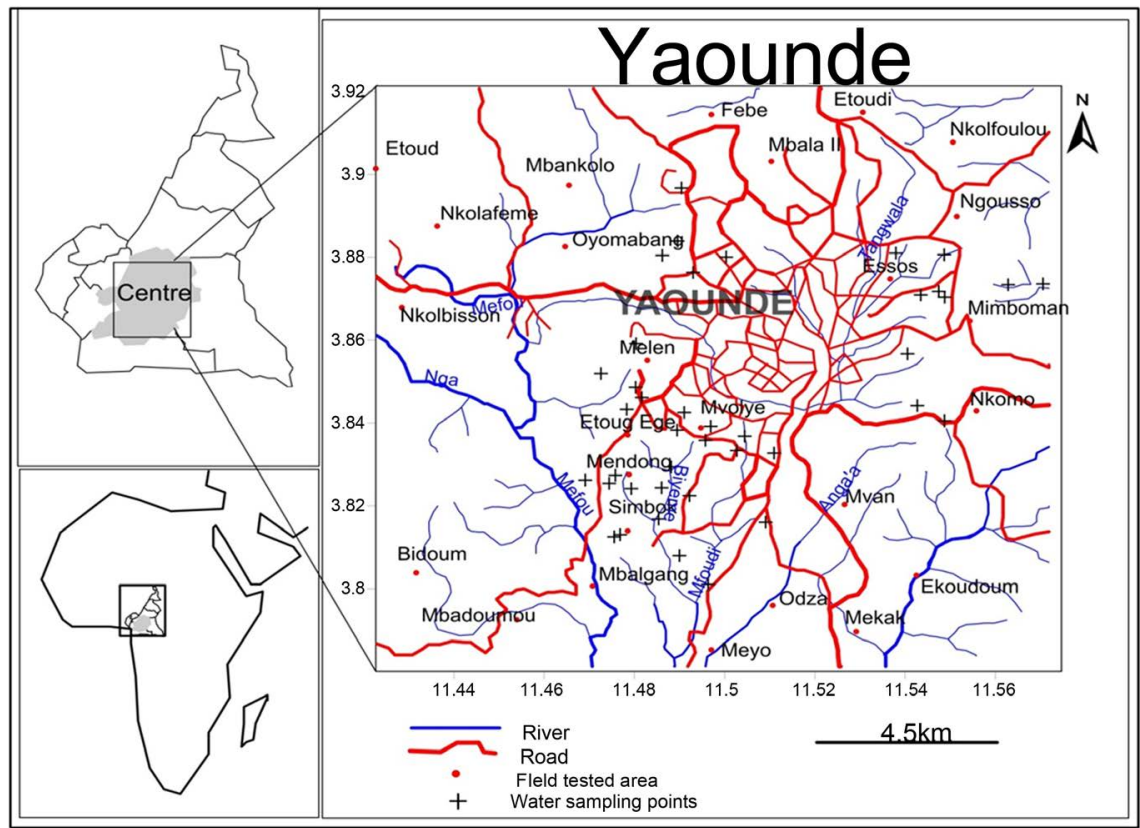

Figure 1. Study location map; Drainage, field tested wells and sample collection points in Yaoundé.

are a group of rocks that outcrop extensively around the Yaoundé city. They belongs to a regional scale mapped unit thrusted southwards unto to the Congo craton that resulted from the collision of the northern Cameroon basin and the Congo craton to the south. As a result of this collision, rocks of the Yaoundé series were squeezed and pushed over the Ntem and Nyong complexes by thrusting. Following this collision, the rocks of the northern Cameroon basement and those of the Congo carton were then fused together by the Yaoundé series to form a suture zone leading to the Yaoundé series having a high dip to the south. The Yaoundé series comprises of low to high garnet-bearing metapellites and orthogneisses metamorphosed under a medium to high pressure metamorphism reaching the granulite facies $\left(\mathrm{T}=750^{\circ} \mathrm{C}-800^{\circ} \mathrm{C}\right.$ and $\left.\mathrm{P}=100-1200 \mathrm{Mpa}\right)$. Meta-intrusive rocks include mafic to intermediate rocks; pyroclasites and serpentinized chromite and nickel, ferrous ultramafic rocks associated with gabbro, diorites and mafic dykes. The Yaoundé gneisses were probably derived from the metasediments of shales and greywacke deposited in an extensional environment related to the Congo craton (Nzenti et al., 1988). This basement consists of insoluble and impervious migmatites, gneisses and schists transpierced by faults and diaclases that give fissure permeability to the anisotropic and heterogeneous formations, which are highly weathered, producing predominantly well-drained Ferralitic soils. These weathered soils with relics of fractures from the pristine rocks serve as aquifers for shallow groundwater, while fractures and faults in deeper unaltered rock constitute the deeper aquifer. The hydrodynamic functioning of the weathered horizon-fresh rock system acts as a two layer aquifer components because the weathered zone contains the groundwater, which is drained by fractures in the rocks. The weathered horizon constitutes a shallow 
aquifers with thickness that varies from about 1 to $20 \mathrm{~m}$, with a hydraulic conductivity from $10^{-4}$ to $10^{-6} \mathrm{~m} / \mathrm{s}$. Due to the undulating nature of the relief, the shallow aquifer gives rise to springs that oozes at the base of slopes forming spring lines and wetlands, which serve as discharge zones (springs and shallow wells) of water for domestic use and subsistence agriculture (Djeuda et al., 1999; Mvondo et al., 2007; Fouepe et al., 2011; Teikeu et al., 2016).

\section{Methodology/Procedures and Data Used}

An extensive field program of borewell; data acquisition, field hydrogeological measurement/tests, water quality sampling and laboratory analysis of collected water was conducted in Yaoundé as follows:

The United States Geological Survey/National Aeronautics and Space Administration/Shuttle Radar Topography Mission's USGS/NASA SRTM Digital Elevation Model DEM $60 \mathrm{~m}$ data for Yaoundé in decimal degrees and datum WGS84 (SRTM, 2018). This data was projected to the UTM coordinate system and clipped to the extent of the study area. Hydrogeological traverse field mapping was carried out in February - March 2016, 600 usable wells were identified and borehole drillers' records, sandbox sketches, drill cuttings sketches, logs were acquired and converted to thirty-nine (39) lithologs for the study area using LogPlot7. Measurement of: longitudes, latitudes and elevations were carried out over the entire city. Ninety well samples were analyzed 45 samples per season; wet/dry for various sites in Yaoundé Table 1. Thirty-eight bore

Table 1. Codesand location of water samples for chemical analysis for major anions and cations.

\begin{tabular}{|c|c|c|c|c|c|c|c|c|c|c|c|}
\hline \multicolumn{12}{|c|}{ Location of Samples for chemical analysis } \\
\hline \multicolumn{2}{|c|}{ Location } & \multicolumn{2}{|c|}{ Coordinates } & \multicolumn{2}{|c|}{ Location } & \multicolumn{2}{|c|}{ Coordinates } & \multicolumn{2}{|l|}{ Location } & \multicolumn{2}{|c|}{ Coordinates } \\
\hline Name & Code & $\mathrm{E}$ & $\mathrm{N}$ & Name & Code & $\mathrm{E}$ & $\mathrm{N}$ & Name & Code & $\mathrm{E}$ & $\mathrm{N}$ \\
\hline Nsam-1 & 1 & 11.6519 & 4.0669 & Nkolmesseng-1 & 16 & 11.7908 & 3.9269 & Madagascar-1 & 31 & 11.5878 & 3.8919 \\
\hline Ekie & 2 & 11.5528 & 3.8272 & Essos & 17 & 11.5435 & 3.8727 & Madagascar-2 & 32 & 11.5056 & 4.0892 \\
\hline Mvan & 3 & 11.5148 & 3.8174 & Nkolmesseng-3 & 18 & 11.7686 & 3.9511 & Madagascar-3 & 33 & 11.6450 & 4.0275 \\
\hline Nsimeyong & 4 & 11.4914 & 3.8369 & Djongolo & 19 & 11.5227 & 3.8844 & Mballa-II & 34 & 11.5257 & 3.9011 \\
\hline Ngoaekele & 5 & 11.5016 & 3.8649 & Nkolmesseng-5 & 20 & 11.7889 & 4.0986 & Madagascar-5 & 35 & 11.6019 & 4.1056 \\
\hline Tamtam-1 & 6 & 11.5636 & 4.0283 & Etoug-ebe-1 & 21 & 11.6950 & 4.0019 & Mimbomann-1 & 36 & 11.6317 & 3.9811 \\
\hline Mvogmbi & 7 & 11.5189 & 3.8422 & Etoug-ebe-2 & 22 & 11.7164 & 4.0467 & Mimbomann-2 & 37 & 11.7642 & 3.9781 \\
\hline Mvogada & 8 & 11.5308 & 3.8624 & Bastos & 23 & 11.5122 & 3.8966 & Ngousso & 38 & 11.5831 & 3.9050 \\
\hline Mvogbesi & 9 & 11.4822 & 3.8637 & Etoug-ebe-4 & 24 & 11.5650 & 3.8828 & Ekounou & 39 & 11.6897 & 4.0139 \\
\hline EligEffa & 10 & 11.5021 & 3.8708 & Etoug-ebe-5 & 25 & 11.6936 & 4.0881 & Nkomo 1 & 40 & 11.7897 & 3.9533 \\
\hline Simbock-1 & 11 & 11.6358 & 4.0172 & Damas-1 & 26 & 11.5942 & 3.9328 & Kondengui 1 & 41 & 11.6467 & 3.9556 \\
\hline Citévert & 12 & 11.4940 & 3.8725 & Damas-2 & 27 & 11.5175 & 3.8183 & Kondengui 2 & 42 & 11.6789 & 3.9733 \\
\hline Briqueterie & 13 & 11.5239 & 3.8851 & Damas-3 & 28 & 11.5281 & 3.9450 & Nkomo 2 & 43 & 11.7903 & 3.9558 \\
\hline Simbock-4 & 14 & 11.5069 & 3.9753 & Oliga & 29 & 11.4929 & 3.8976 & Nkolndongo & 44 & 11.7489 & 3.9267 \\
\hline Simbock-5 & 15 & 11.6181 & 3.9950 & Damas-5 & 30 & 11.7097 & 3.9311 & EkounouKoayos & 45 & 11.7550 & 4.0089 \\
\hline
\end{tabular}


well logs were used together with structural data to determine the aquifer setting. The field acquired data were mounted on GIS platforms to create sample location, drainage and water level contour maps Figure 1. The city of Yaoundé was then divided into twenty zones and each zone covered by two field workers responsible for thirty 30 out of preselected 600 wells; 550 Dug wells and 50 Bore wells.

Forty fieldworkers (Undergraduate geology students) were trained in April 2016 to use field equipment in Table 2, collect data, record data on data sheets and a reconnaissance survey to identify the pre-selected wells and self-introduction to private well owners for access/permissions. Four seasonal; single-day tests/measurements were carried out in June 2016 (Dry-wet season), September 2016 (Wet season), December 2016 (Wet-dry season) and March 2017 (Dry season) respectively. During each season, twenty commercial bikes (Bensikins) were hired for four hours each field day 8 am - 12 noon simultaneously in all the twenty zones. Two field workers per bike measured/tested for the following in situ: Wells: Surface elevation, Well water level and Well depths. Groundwater: Electrical conductivity EC, $\mathrm{pH}$, Total dissolved solids TDS and Temperature ${ }^{\circ} \mathrm{C}$ on 445 wells; 425 hand dug wells and 20 boreholes. 125 handdug wells and 30 boreholes with incomplete data were removed from the reconnaissance selected set of 600 wells due to:

1) Borehole access was impossible in the course of the study by private owners being absent on fixed data collection dates or access denied after initial acceptance.

2) Hand dug wells got dry in one or more season(s) in the course of the study.

3) Inconsistent data due to field workers' errors or high laboratory result ionic balance error $(>10 \%)$.

Table 2. Field Equipment, Softwares, their specifications and functions.

\begin{tabular}{|c|c|c|}
\hline Equipment/Softwares & Specifications & Functions \\
\hline Bike & Commercial bikes (Bensikin) & To transport fieldworkers to wells \\
\hline GPS & GARMIN GPSMAP 60CSx & To measure longitude, latitude and elevation of wells \\
\hline EC Meter & HANNA HI 98304/HI98303 & To measure Electrical Conductivity of water. \\
\hline pH Meter & HANNA HI 98127/HI98107 & To measure $\mathrm{pH}$ of water. \\
\hline Water level indicator & Solinst Model 102M & To indicate static water levels of water in wells \\
\hline Measuring Tape & Weighted measuring tape & Measurement of well diameter and depth. \\
\hline Digital Thermometer & Extech $39240\left(-50^{\circ} \mathrm{C}\right.$ to $\left.200^{\circ} \mathrm{C}\right)$ & To measure temperature of water \\
\hline TD S meter & Hanna HI 96301 with ATC & To measure Total dissolved solids in water \\
\hline Water sampler & Gallenkampf $1000 \mathrm{ml}$ & To collect well water sample from well \\
\hline Sample bottles & Polystyrene $1000 \mathrm{ml}$ & To hold sample for onward transmission to laboratory \\
\hline ArcGIS & Version 10.1 & GIS Drawing sampling/Tests location maps \\
\hline Global Mapper & Version 11 & GIS Geolocation of wells \\
\hline Surfer Golden Software & Version 12 & GIS plotting contours for spatial distribution \\
\hline AqQA/Aquachem & Version 15 & For the analysis/interpretation of water chemistry results \\
\hline Rockworks & Version 16 & For the analysis/interpretation of water chemistry results \\
\hline Logplot & Version 7 & For production of lithologs from borehole logs/data \\
\hline
\end{tabular}


8900 groundwater physico-chemical field tests; 445 wells ${ }^{\star} 5^{\star} 4$ seasons for EC, $\mathrm{pH}$, TDS, Temperature, Depth to water carried out during these four seasons. Ninety groundwater samples were collected. Two selected wells per zone were sampled for two seasons; wet and dry; one out of every fifteen tested wells. Two samples for chemical analysis were collected at each site. One sample was filtered using Sartorius polycarbonate filtering apparatus and a $0.45 \mu \mathrm{m}$ cellulose acetate filter membrane, acidified with Merck ultra-pure nitric acid to $\mathrm{pH}<2$ in situ in sample-rinsed high density linear polyethylene (HPDE) $50 \mathrm{ml}$ bottles. The other sample was unfiltered into $50 \mathrm{ml}$ bottles with sealed lids as per sampling protocols (ISO 5667-3 2003; ISO 5667-1 2006; ISO 5667-11 2009; Barcelona et al., 1985). All the collected pre-labeled sample-water-rinsed bottles were sent to Actlabs Canada to analyze for (APHA, 1995):

1) Major cations in mg/L: $\mathrm{Ca}^{2+}, \mathrm{Mg}^{2+}, \mathrm{Na}^{+}, \mathrm{K}^{+}$and $\mathrm{NH}_{4}^{+}$.

2) Major anions in $\mathrm{mg} / \mathrm{L}: \mathrm{HCO}_{3}^{-}, \mathrm{Cl}^{-}, \mathrm{SO}_{4}^{2-}, \mathrm{HPO}_{4}^{2-}$ and $\mathrm{NO}_{3}^{-}$.

3) Trace elements; results not evaluated here.

For a better understanding of the rock-water interactions, evolution of the hydrogeochemistry, water quality evaluation for human consumption, comparing the water types and interpretation of seasonal variations in hydrochemical processes and suitability for agro-industrial use; Durov's diagram, Piper's diagram, Gibbs diagram, USSL ratio, Sodium Absorption ratio SAR, Percent sodium \%Na, Kelly Ratio KR, Magnesium Absorption Ratio MAR, Total Hardness TH, Residual Sodium Carbonate RSC, Permeability Index PI and the field physico-chemical and laboratory analysis data were mounted unto various software platforms Table 3 to get indices/parameters and figures for interpretation.

Table 3. Formulae for the determination for indices/parameters for water quality assessment.

\begin{tabular}{|c|c|c|}
\hline Indices & Formula & Reference \\
\hline Percentage Sodium, Na\% & $\% \mathrm{Na}=\frac{\mathrm{Na}^{+}+\mathrm{K}^{+}}{\mathrm{Na}^{+}+\mathrm{K}^{+}+\mathrm{Ca}^{2+}+\mathrm{Mg}^{2+}} \times 100$ & Wilcox (1955) \\
\hline Kelly Ratio, KR & $\mathrm{KR}=\frac{\mathrm{Na}^{+}}{\mathrm{Ca}^{2+}+\mathrm{Mg}^{2+}}$ & Kelley (1940) \\
\hline $\begin{array}{c}\text { Magnesium Absorption Ratio, } \\
\text { MAR }\end{array}$ & $\operatorname{MAR}=\left(\frac{\mathrm{Mg}^{2+}}{\mathrm{Mg}^{2+}+\mathrm{Ca}^{2+}}\right) \cdot 100$ & Szaboles \& Barab (1964) \\
\hline Total Hardness, HT & $\mathrm{TH}\left(\mathrm{CaCO}_{3}\right) \mathrm{mg} / \mathrm{L}=2.5 \mathrm{Ca}^{2+}+4.1 \mathrm{Mg}^{2+}$ & Todd (1980) \\
\hline $\begin{array}{l}\text { Residual Sodium Carbonate, } \\
\text { RSC }\end{array}$ & $\mathrm{RSC}=\left(\mathrm{CO}_{3}+\mathrm{HCO}_{3}-(\mathrm{Ca}+\mathrm{Mg})\right)$ & $\begin{array}{l}\text { Eaton (1950) and } \\
\text { Raghunath (1987) }\end{array}$ \\
\hline $\begin{array}{l}\text { Sodium Absorption Ratio, } \\
\text { SAR }\end{array}$ & $\mathrm{SAR}=\frac{\mathrm{Na}}{\sqrt{\frac{\mathrm{Ca}+\mathrm{Mg}}{2}}}$ & Richards (1954) \\
\hline Permeability Index, PI & $\mathrm{PI}=\frac{\left((\mathrm{Na}+\mathrm{K})+\sqrt{\mathrm{HCO}_{3}}\right) * 100}{\mathrm{Ca}+\mathrm{Mg}+\mathrm{Na}+\mathrm{K}}$ & Doneen (1962) \\
\hline Water Quality Index, WQI & $\mathrm{WQI}=\sum_{i=1}^{n} W_{i} q_{i}\left[\sum_{i=1}^{n} W_{i}\right]$ & $\begin{array}{c}\text { Sisodia \& } \\
\text { Moundiotiya (2006) }\end{array}$ \\
\hline
\end{tabular}




\section{Results and Discussion}

\subsection{Aquifer Setting and Flow Patterns}

\subsubsection{Aquiferous Lithologies in Yaoundé}

The aquiferous formations in Yaoundé are made up from top to bottom; top soil 0.50 - $9.00 \mathrm{~m}$, clayey Sand $1.00-25.00 \mathrm{~m}$, Silty mottled clay containing preserved fractures $10.00-42.10 \mathrm{~m}$, Ferralitic Laterite $1.60-37.30 \mathrm{~m}$, fractured weathered gneiss and unweathered fractured gneiss and migmatites of the Yaoundé series $1.50-38.00 \mathrm{~m}$ in thickness, up to a total depth of $84 \mathrm{~m}$ Figure 2 .
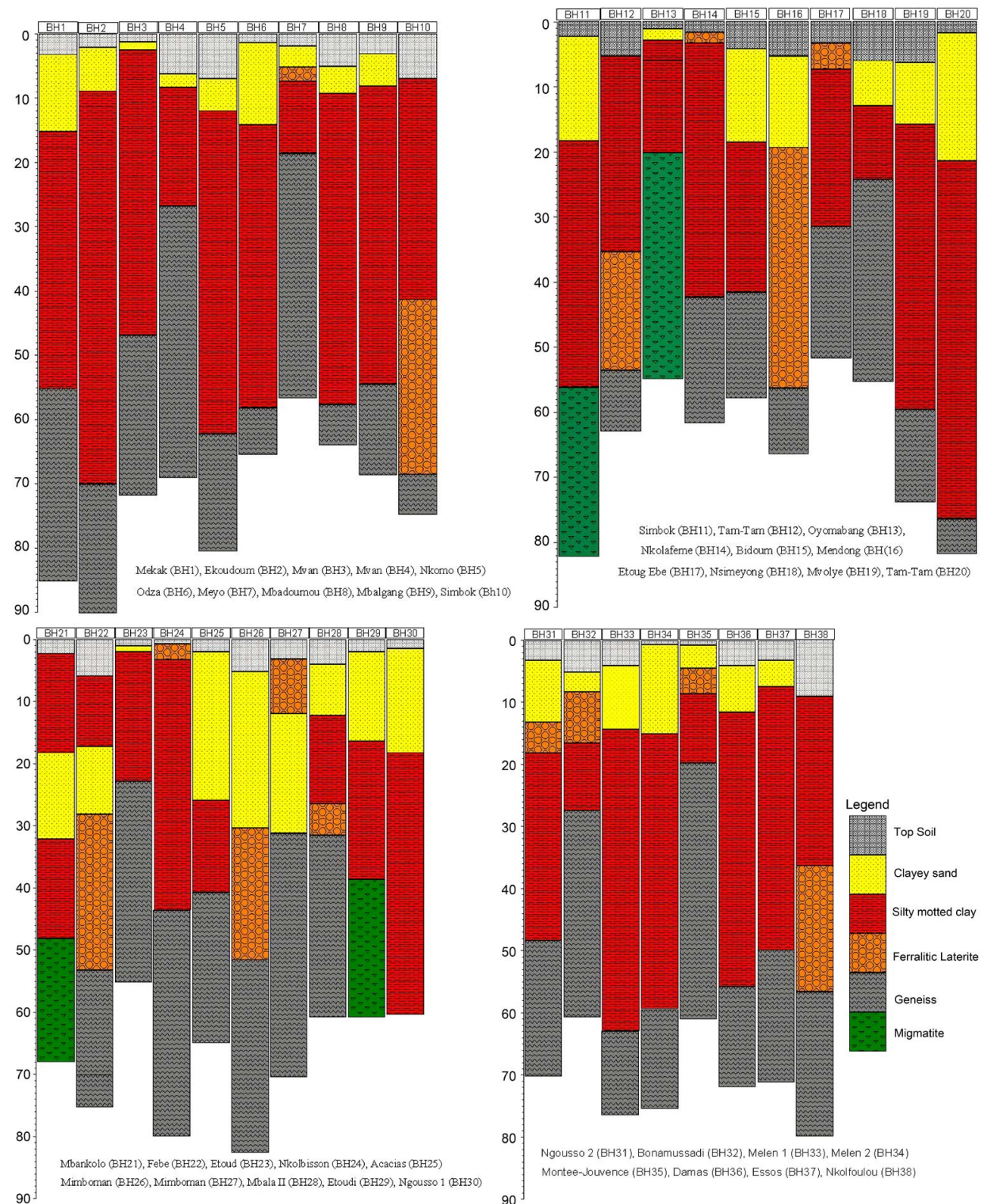

Figure 2. Borehole lithostratigraphic logs, Yaoundé: (a) Borehole 1 - 10, Borehole 11 - 20, (c) Borehole $21-30$ and (d) Borehole 31 - 38. Lithology thickness ranges between: Top soil $0.50-9.00 \mathrm{~m}$, Clayey Sand $1.00-25.00 \mathrm{~m}$, Silty mottled clay $10.00-42.10$, Ferralitic Laterite $1.60-37.30 \mathrm{~m}$ and Gneiss $1.50-38.00$. 
Fractured basement and weathered layers of crystalline rocks form two major types of aquifers important for water supply in hard rock areas. These weathering profiles generally develop under both stable geodynamic conditions where weathering rate far exceeds erosion rate with important amounts of precipitation and high temperatures (Wyns et al., 2004).

\subsubsection{Digital Elevation Model}

Yaoundé has an undulating relief of hills and valleys. The land surface is covered by top soil in most areas though there are some areas where gneisses outcrop on hill tops and valleys Figure 3. Tectonic structures are hardly visible but for some joints and fissures.

\subsubsection{Subsurface Structural Fissures}

Subsurface structural fissures in the study area are mostly fissures and fractures Figure 4. These structures are covered by weathered regolith and saprolite making their mapping by traditional geological field methods difficult. They are mostly revealed through GIS Remote sensing and geostatistical analysis (Teikeu et al. 2016). They reveal local (red), intermediate (green) and regional (blue) scaled fissure host to groundwater.

\subsubsection{Water Level Fluctuations and Well Depths}

1) Depth-to-water values $(\mathrm{m})$ of groundwater in wells in Yaoundé range from: 0.40 - 22.30 in the Wet season; $0.64-22.42$ in the Wet/dry season; $1.31-21.56$ in the Dry season to 1.95 - 23.30 in the Dry/wet season Figure 5.

2) Borewells have depths of $17 \mathrm{~m}-83 \mathrm{~m}$ while Dugwells range in depth from $80 \mathrm{~cm}$ at the valleys to $19 \mathrm{~m}$ at higher altitudes. Most shallow dugwells $<5 \mathrm{~m}$ at elevations above $660 \mathrm{~m}$ dried up completely in the Dry/wet season 4.

3) Surface elevation and Groundwater contours

The surface elevation and groundwater contours are mostly concentric around the hills and are a direct replica of surface morphology Figure 6. This indicates

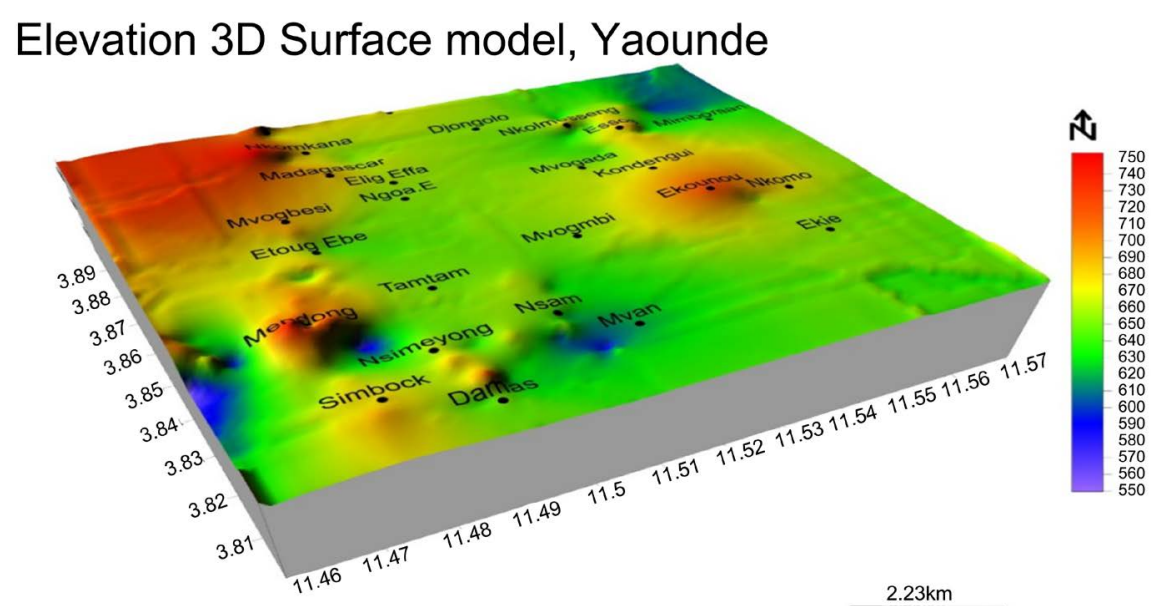

Figure 3. Digital Elevation Model DEM of Yaoundé with an undulating relief of hills and valleys. 


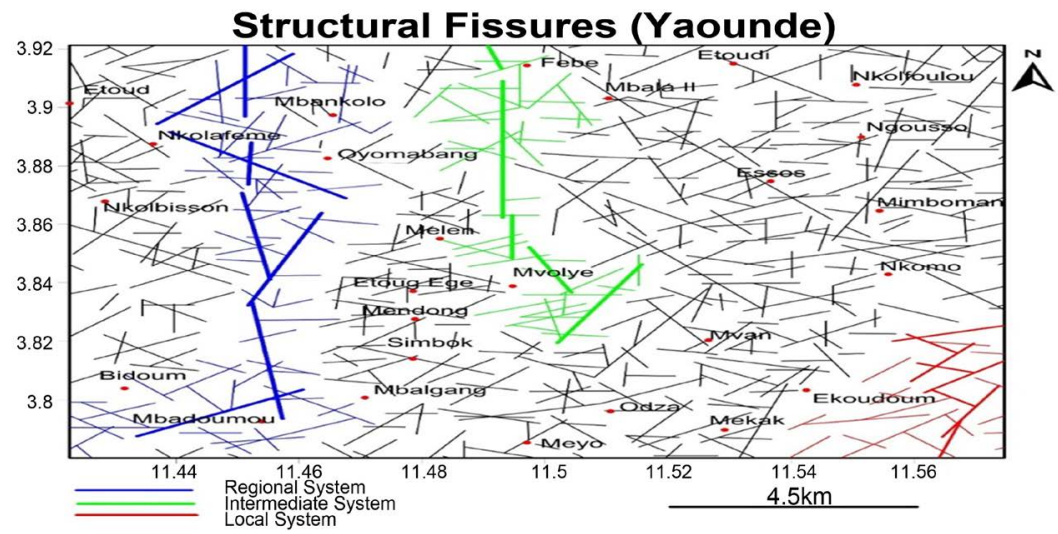

Figure 4. GIS Remotely sensed subsurface structural fissures in study area: The local (red ) around Ekoudoum; intermediate (green) running from Mont Febe to Mvolye and regional scaled fissures (blue) from Mbankolo to Mbadoumou, host to groundwater (Extracted from Teikeu et al. 2016).

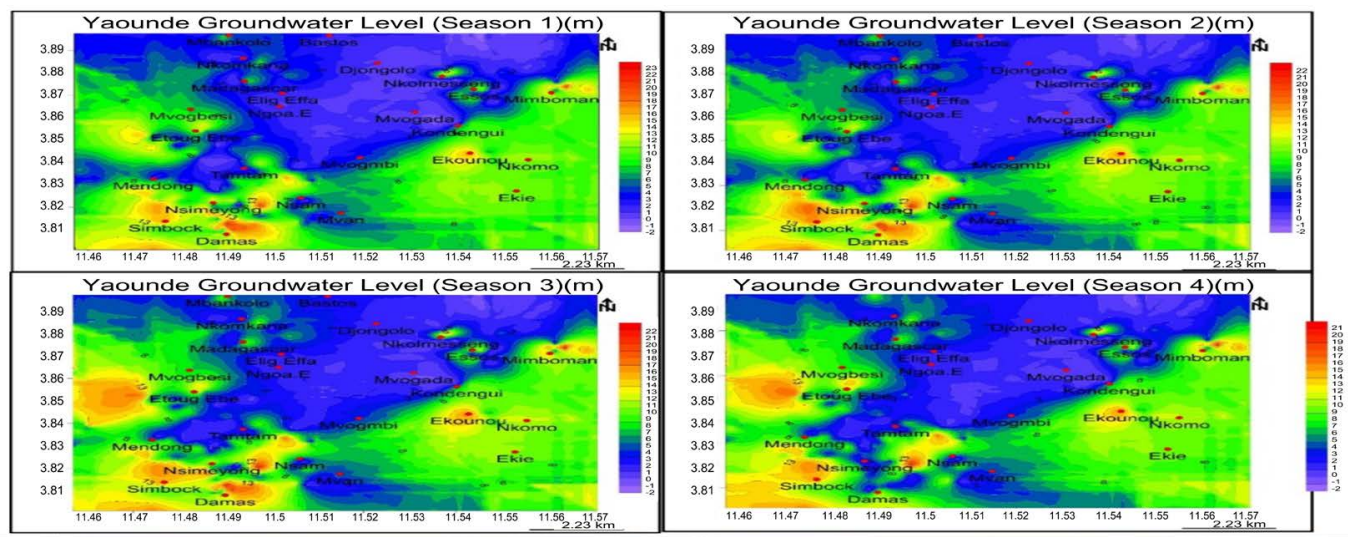

Figure 5. Depth-to-water level of wells in Yaoundé during four hydrogeological seasons; the deepest water levels in red, occur at Etoug-Ebe, Simbok, Damas and Mimboman in the dry season while the shallow water levels are during the wet season 1.

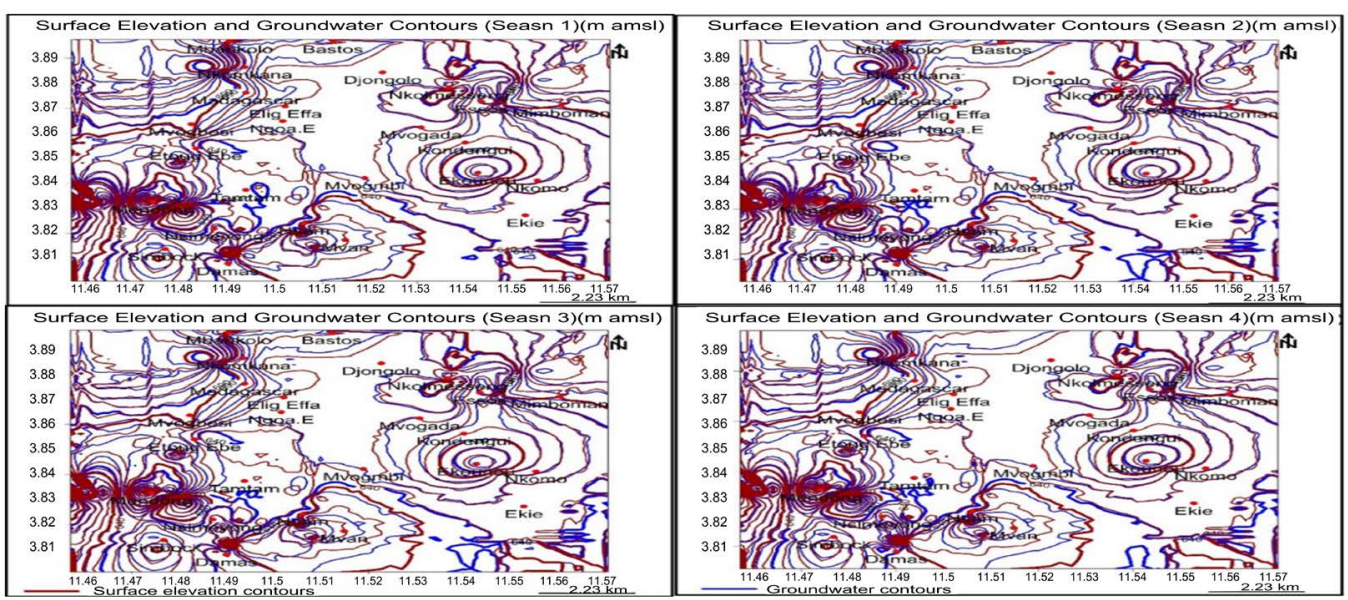

Figure 6. Surface elevation and groundwater contours; the similarity in the shape of both contours for all seasons indicate the water level contours are in rhythm with the surface topography for all seasons indicative of a single phreatic aquifer. Both contours are concentric around hills indicating topography controlled piston flow. 
the groundwater levels are similar to surface elevation in profile typical of phreatic aquifers.

\subsection{Hydrogeochemistry}

\subsubsection{Seasonal Variations in Physicochemical Parameters of Groundwater in Yaoundé}

1) $\mathrm{pH}$ values of Yaoundé groundwater range from: $4.0-8.8$ in the Wet season to $2.6-12.0$ in the Dry/wet season Figure 7. The $\mathrm{pH}$ values vary with season indicating seasonal control. Some dugwells have anomalously low $\mathrm{pH}$ possibly due to anthropogenic pollution from runoff leachates from dumpsites during the wet season and high values due to intense photosynthetic activity by algae which were visible in almost dry shallow wells in the Dry/wet season. In waters with low dissolved solids as found in Yaoundé, which consequently have a low buffering capacity i.e. low internal resistance to $\mathrm{pH}$ change. Changes in $\mathrm{pH}$ induced by external causes may be quite dramatic from point to point and from season to season. Extremes of $\mathrm{pH}$ can affect the palatability of water but the corrosive effect on distribution systems is a more urgent problem.

2) Total Dissolved Solids (TDS) $(\mathrm{mg} / \mathrm{L})$ values of Yaoundé groundwater range from: $4-650$ in the wet to $0.01-800$ in the dry season Figure 8 . The TDS vary with season indicating seasonal control.

3) Temperature $\mathrm{T}{ }^{\circ} \mathrm{C}$ values of Yaoundé groundwater range from: 21.0 - 27.5 in the wet season to 19.5 - 27.5 in the dry season Figure 9. The temperatures vary with season indicating seasonal control.

4) Electrical conductivity EC $\mu \mathrm{S} / \mathrm{cm}$ values of Yaoundé groundwater range from $10-1300$ in the wet season, $90-1690$ in the dry/wet season Figure 10. The EC varied with season indicating seasonal influence. The residual salinity hazard RSH for the four seasons Table 4. The $\mathrm{S}_{1} \mathrm{C}_{0}, \mathrm{~S}_{1} \mathrm{C}_{1}$, and $\mathrm{S}_{1} \mathrm{C}_{2}$ make up the excellent, very good and good Classes respectively. For the Wet season 430 samples,

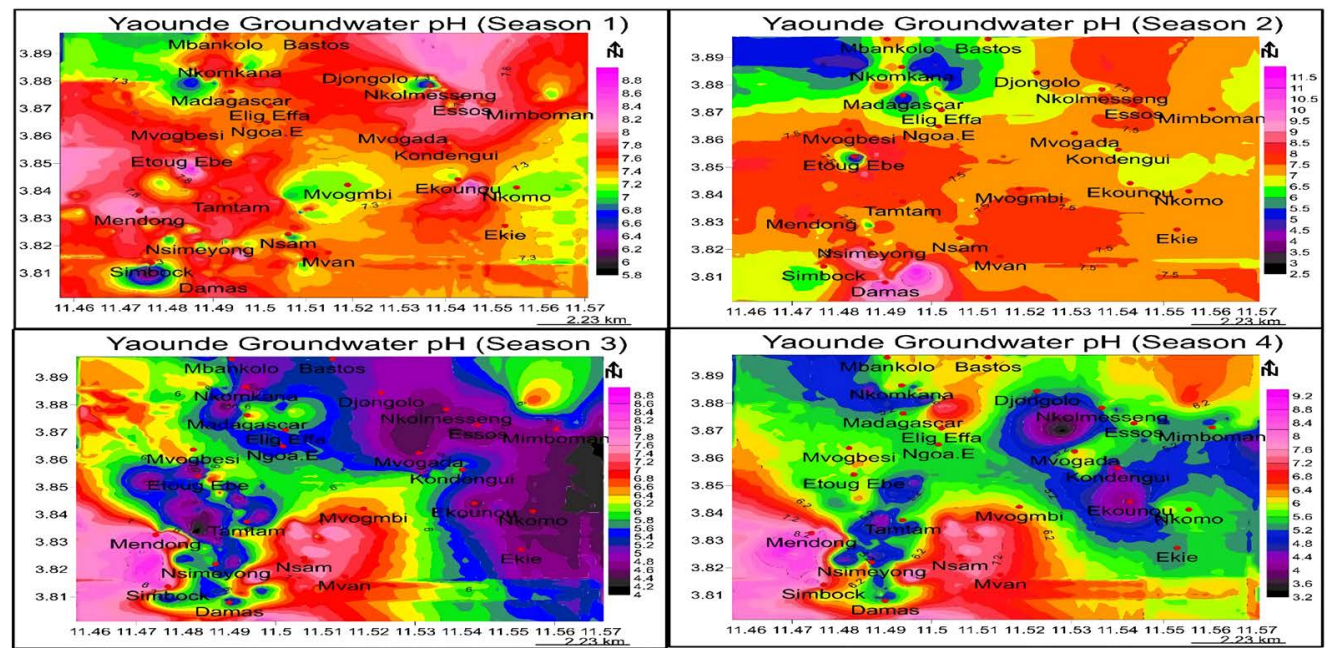

Figure 7. Yaoundé groundwater $\mathrm{pH}$ values for four seasons; groundwater is alkaline in the rainy season; alkaline to slightly acidic in the wet/dry season; acidic in the dry season and acidic to slightly alkaline in the dry/wet season. 


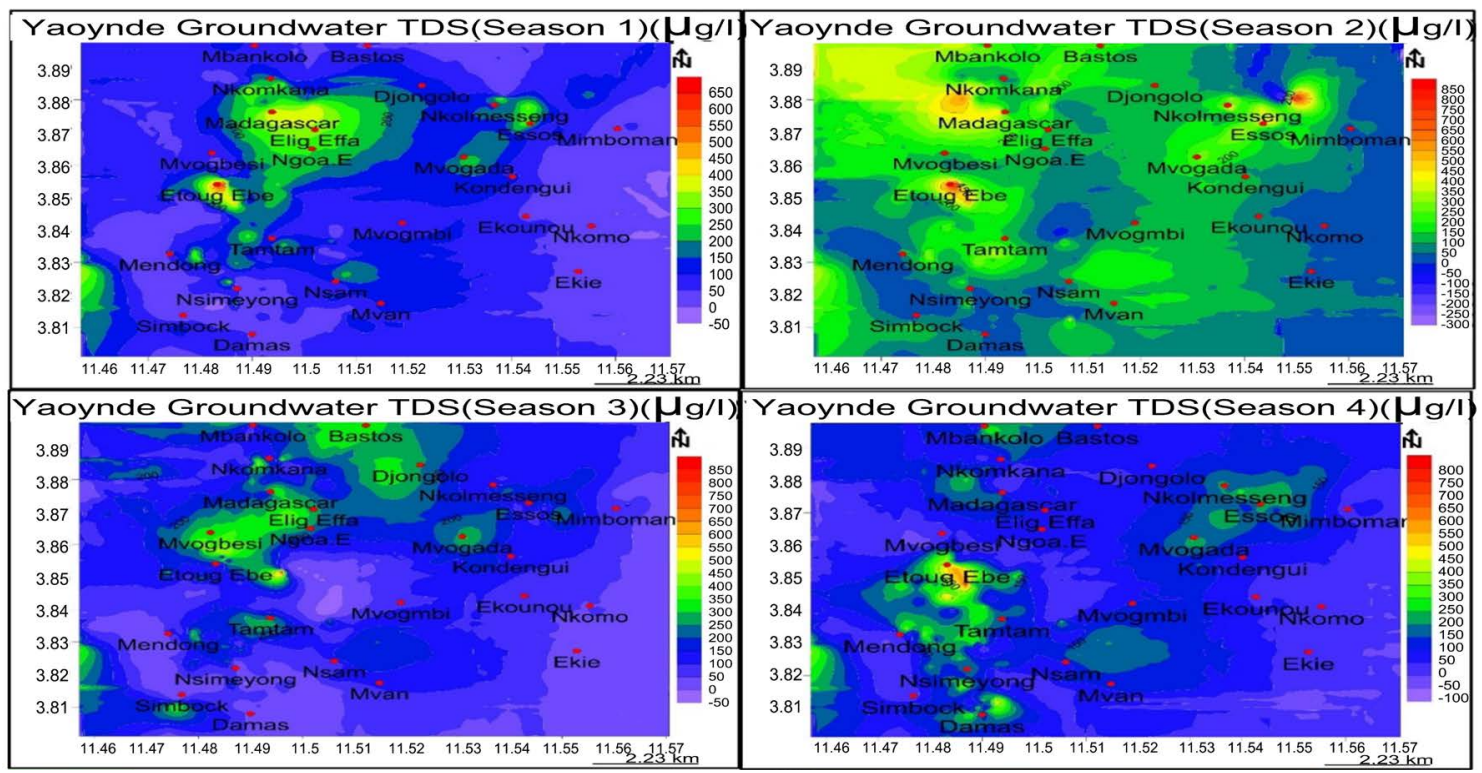

Figure 8. Yaoundé groundwater TDS values for four seasons; groundwater is fresh $<650$ in the rainy season; fresh $<850$ in the wet/dry season; fresh $<850$ in the dry season and fresh $<800$ in the dry/wet season.

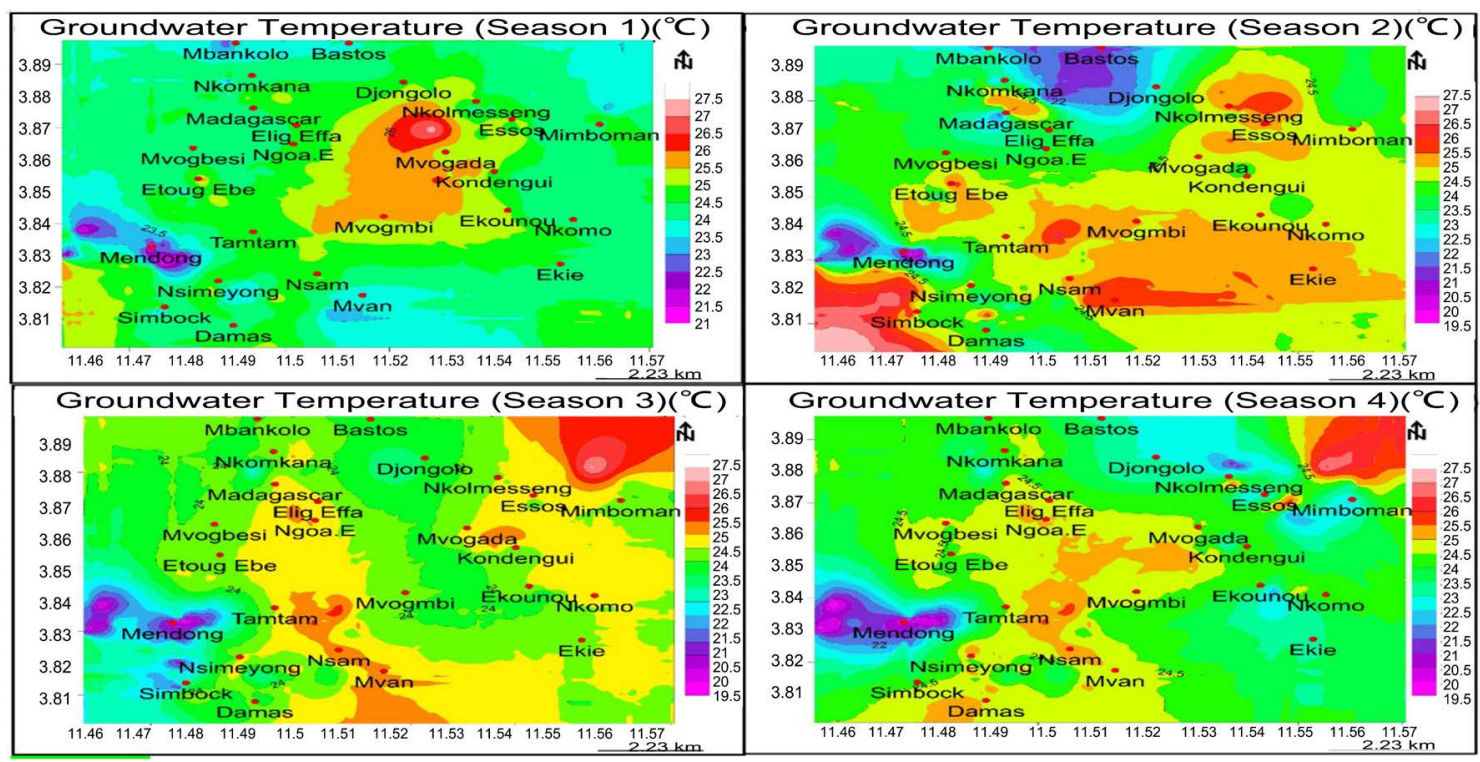

Figure 9. Yaoundé groundwater temperature ${ }^{\circ} \mathrm{C}$ values for four seasons; 21.0 - 27.5 in the rainy season; 19.5 - 27.5 in the wet/dry season; 19.0 - 27.5 in the dry season and 19.5 - 27.5 in the dry/wet season.

96.7\%; Wet/dry 424 samples, 95.3\%; Dry season 433 samples $97.3 \%$ and Dry/wet season 431 samples, $96.9 \%$ are thus considered as good for residual salinity hazard based on the electrical conductivity Figure 10 (Figure 11).

\subsubsection{Groundwater Content of Major Ions $\mathrm{mg} / \mathrm{L}$ Table 5}

The occurrence of ions in groundwater in Yaoundé in decreasing order of magnitude: for cations; $\mathrm{Ca}^{2+}>\mathrm{K}^{+}>\mathrm{Mg}^{2+}>\mathrm{Na}^{+}>\mathrm{NH}_{4}^{+}$and anions; $\mathrm{HCO}_{3}^{-}>\mathrm{Cl}^{-}>$ $\mathrm{SO}_{4}^{2-}>\mathrm{NO}_{3}^{-}>\mathrm{HPO}_{4}^{2-}$. The evaluation of ions is based on recommended guideline values (WHO, 2017) (Table 6). 


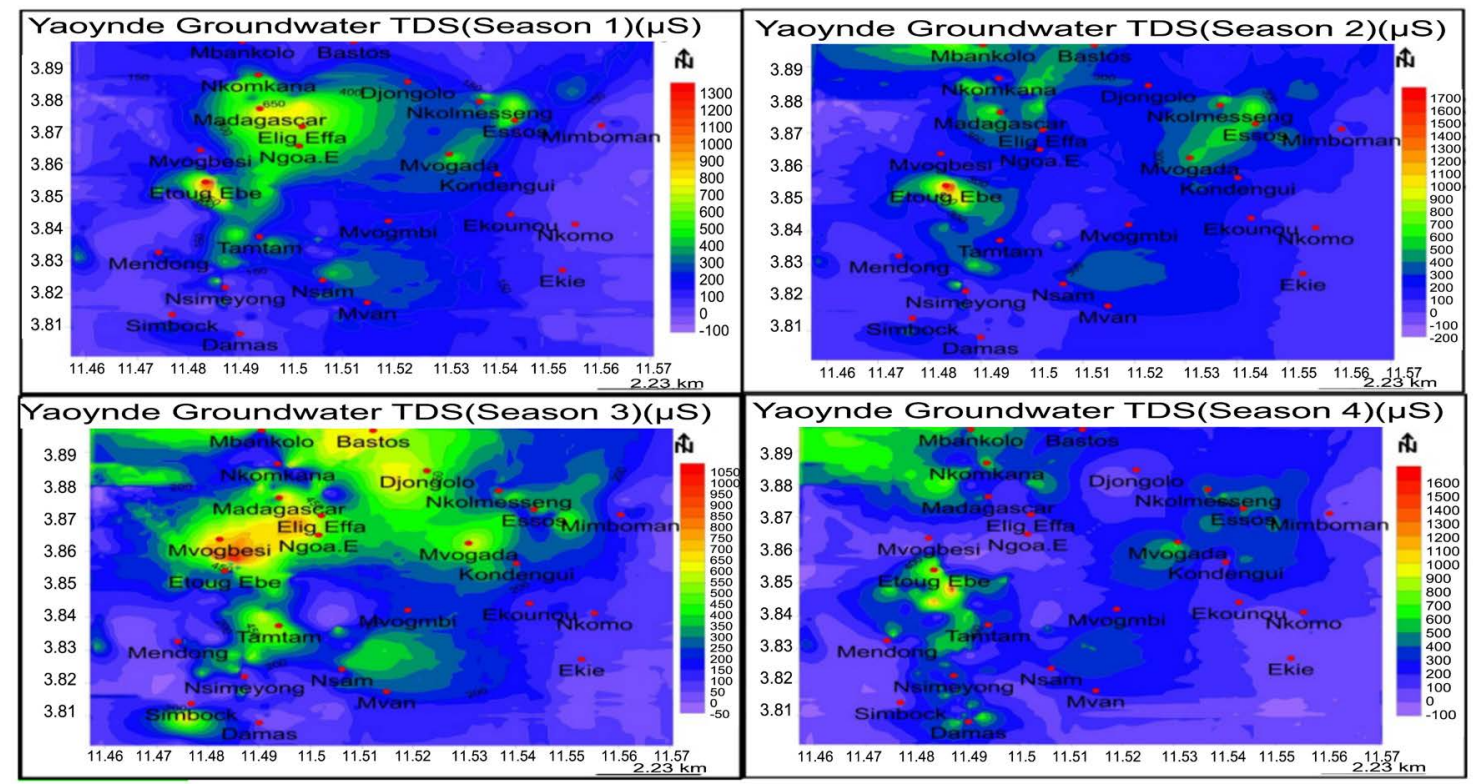

Figure 10. Yaoundé groundwater Electrical Conductivity EC values $\mu \mathrm{S} / \mathrm{cm}$ for four seasons range from: 10 - 1300 in the wet season; 20 - 1700 in the Wet/Dry season; 50 - 1050 in the dry season to 90 - 1600 in the dry/wet season.

Table 4. Summary statistics of physico-chemical groundwater parameters of 445 wells measured in situ during four hydrogeological seasons (Wet, Wet/Dry, Dry, and Dry/wet), Yaoundé.

\begin{tabular}{cccccccccccccc}
\hline Season & & Wet & \multicolumn{4}{c}{ Wetdry } & \multicolumn{3}{c}{ Dry } & \multicolumn{3}{c}{ Drywet } \\
\hline Parameter & Min & Max & Av & Min & Max & Av & Min & Max & Av & Min & Max & Av \\
\hline Depth to water $(\mathrm{m})$ & 0.40 & 22.30 & 1.22 & 0.64 & 22.42 & 1.86 & 1.31 & 21.56 & 2.41 & 1.95 & 23.30 & 4.22 \\
$\mathrm{pH}$ & 4.0 & 8.8 & 7.8 & 3.4 & 9.0 & 7.5 & 6.2 & 9.0 & 6.0 & 2.6 & 12 & 5.6 \\
$\begin{array}{c}\text { Electrical conductivity } \\
(\mu \mathrm{S} / \mathrm{cm})\end{array}$ & 10 & 1300 & 246 & 20 & 1700 & 348 & 50 & 1050 & 452 & 90 & 1690 & 276 \\
$\begin{array}{c}\text { Temperature }\left({ }^{\circ} \mathrm{C}\right) \\
\begin{array}{c}\text { Total dissolved solids } \\
(\mathrm{mg} / \mathrm{l})\end{array}\end{array}$ & 19.0 & 27.5 & 24.8 & 19.0 & 27.5 & 25.3 & 21.0 & 28.0 & 23.6 & 19.5 & 27.5 & 25.0 \\
\hline
\end{tabular}

Table 5. Water quality Classification based on EC of Yaoundé groundwater.

\begin{tabular}{ccccccccccc}
\hline \multirow{2}{*}{$\begin{array}{c}\text { Hazard } \\
\text { Class }\end{array}$} & \multirow{2}{*}{ EC $\mu \mathrm{S} / \mathrm{cm}$} & \multirow{2}{*}{ Quality } & \multicolumn{2}{c}{ Season1 } & \multicolumn{2}{c}{ Season2 } & \multicolumn{2}{c}{ Season3 } & \multicolumn{2}{c}{ Season4 } \\
& & & No & $\%$ & No & $\%$ & No & $\%$ & No & $\%$ \\
\hline C0 & $0-100$ & Excellent & 141 & 31.7 & 118 & 26.5 & 112 & 25.2 & 112 & 25.2 \\
C1 & $101-250$ & Very Good & 149 & 33.5 & 145 & 32.6 & 156 & 35.1 & 154 & 34.6 \\
C2 & $251-750$ & Good & 140 & 31.5 & 161 & 36.2 & 165 & 37.0 & 165 & 37.1 \\
C3 & $751-2250$ & Doubtful & 15 & 3.4 & 21 & 4.7 & 11 & 2.5 & 13 & 29.2 \\
C4 & $>2250$ & Unsuitable & 0 & 0 & 0 & 0 & 1 & 0.2 & 1 & 0.2 \\
\hline
\end{tabular}

1) Sodium ionic concentration values of Yaoundé groundwater range from: $0.05-3.31$ in Wet season to $0.05-3.42$ in the Dry season. Sodium regulates blood pressure levels in the human body and increased levels of sodium in blood leads to rise in blood pressure. 


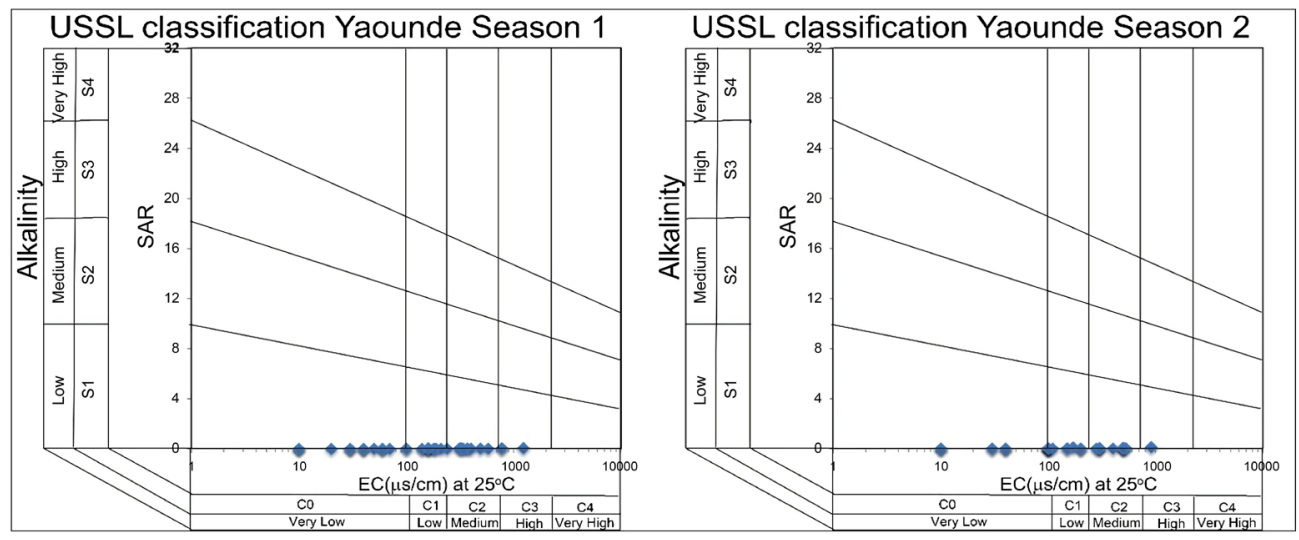

Figure 11. Residual Salinity Hazard Classification, Yaoundé; The samples fall in the $S_{1} C_{0}, S_{1} C_{1}$, and $\mathrm{S}_{1} \mathrm{C}_{2}$ which are; excellent, very good and good Classes respectively. For the Wet season 430 samples, 96.7\%; Wet/dry 424 samples, 95.3\%; Dry season 433 samples, $97.3 \%$ and Dry/wet season 431 samples, $96.9 \%$ are thus considered as good for residual salinity hazard based on the electrical conductivity.

Table 6. Summary of chemical analysis of groundwater analysis of 90 well: 45 wells each season; dry/wet, Yaoundé.

\begin{tabular}{ccccc}
\hline Ions & \multicolumn{2}{c}{ Wet Season } & \multicolumn{2}{c}{ Dry season } \\
\hline & $\min$ & $\mathrm{Max}$ & $\min$ & $\max$ \\
\hline $\mathrm{Na}^{+}$ & 0.05 & 3.31 & 0.05 & 3.42 \\
$\mathrm{~K}^{+}$ & 0.55 & 41.69 & 0.38 & 32.02 \\
$\mathrm{Ca}^{2+}$ & 4.24 & 112.8 & 1.38 & 74.45 \\
$\mathrm{Mg}^{2+}$ & 1.01 & 32.9 & 0 & 14.16 \\
$\mathrm{NH}_{4}^{+}$ & 0.01 & 0.16 & 0 & 30.05 \\
$\mathrm{HCO}_{3}^{-}$ & 2.44 & 368.76 & 4.88 & 287.45 \\
$\mathrm{NO}_{3}^{-}$ & 0 & 4.32 & 0.07 & 64.86 \\
$\mathrm{SO}_{4}^{2-}$ & 0.57 & 14.37 & 0.36 & 25.94 \\
$\mathrm{Cl}^{-}$ & 1 & 184 & 0.32 & 89.2 \\
$\mathrm{HPO}_{4}^{2-}$ & 0 & 0.19 & 0 & 0 \\
$\mathrm{Hardness}^{-}$ & 1.74 & 18.21 & 0.34 & 11.02 \\
\hline
\end{tabular}

2) Potassium ionic concentration values of Yaoundé groundwater range from: 0.55 - 41.69 in the Wet season to 0.38 - 32.02 in the Dry season. Potassium Controls body balance and maintains normal growth of the human body. Deficiency of potassium might lead to weakness of muscles and rise in blood pressure. No standard limits have been provided by the WHO Standards for level of sodium and potassium in drinking water.

3) Calcium ionic concentration ranges from Wet season $4.24-112.8$ and Dry season 1.38 - 74.45. Acceptable limit of calcium in drinking water is $75 \mathrm{mg} / \mathrm{L}$. $200 \mathrm{mg} / \mathrm{L}$ in case of no other alternative source. Calcium ion is necessary for proper mineralization of bones and bone strength. Deficiency in intake of calcium leads to eventual demineralization of bones for complementing the inade- 
quate amounts of calcium in the body.

4) Magnesium ionic concentrations of Yaoundé groundwater range from: 1.01 - 32.9 in the Wet season and $0-14.16$ in the Dry season. Magnesium Acceptable limit in drinking water is $30 \mathrm{mg} / \mathrm{L}(100 \mathrm{mg} / \mathrm{L}$ in case of no other alternative source). Magnesium helps in maintaining normal nerve and muscle function, a healthy immune system and helps bones remain strong. It also helps in regulation of regulate blood glucose levels and aid in the production of energy and protein. Deficiency of magnesium in the human diet might lead to anxiety, fatigue or anorexia.

5) Ammonium $\mathrm{NH}_{4}^{+}$ionic concentrations of Yaoundé groundwater range from: $1.01-32.9$ in the Wet season and 0 - 14.16 in the Dry season. These values are above allowable limits in some areas in both the wet and dry seasons. Ammonium is generally present in natural waters, though in very small amounts, as a result of microbiological activity which causes the reduction of nitrogen-containing compounds. When present in levels above $0.1 \mathrm{mg} / \mathrm{L} \mathrm{N}$, sewage or industrial contamination may be indicated. From the viewpoint of human health the significance of ammonium is marked because it indicates the possibility of sewage pollution and the consequent possible presence of pathogenic micro-organisms.

6) Bicarbonate $\mathrm{HCO}_{3}^{-}$ionic concentrations of Yaoundé groundwater range from: $2.44-368.76$ in the Wet season and $4.88-287.45$ in the Dry season. No standard limits have been provided by the WHO Standards for level of carbonate and bicarbonate in drinking water.

7) Chloride $\mathrm{Cl}^{-}$ionic concentrations of Yaoundé groundwater range from: 1 184 in the Wet season and $0.32-89.2$ in the Dry season. Acceptable limit of chloride in drinking water is $250 \mathrm{mg} / \mathrm{L}(1000 \mathrm{mg} / \mathrm{L}$ in case of no other alternative source) (WHO, 2017). Large amounts of chloride ions leads to bad taste in groundwater. Increase in chloride levels in our body might lead to increase in blood pressure levels and rise in body fluids.

8) Sulphate $\mathrm{SO}_{4}^{2-}$ ionic concentrations of Yaoundé groundwater range from: $0.57-14.37$ in the Wet season and $0.36-25.94$ in the Dry season. The sulphate ion causes no particular harmful effects on soils or plants; however, it contributes in increasing the salinity in the soil solution. Acceptable limit of sulphate in drinking water is $200 \mathrm{mg} / \mathrm{L}$. Excess sulphate consumption through water might lead to occurrence of diarrhoea in humans.

9) Phosphate $\mathrm{HPO}_{4}^{2-}$ ionic concentrations of Yaoundé groundwater range from: $0-0.19$ in the Wet season and 0 in the Dry season. The mean phosphate levels in all seasons for groundwater samples in Yaounde are below the recommended maximum contaminant level. $1.0 \mathrm{mg} / \mathrm{L}$ for drinking water.

10) Nitrate $\mathrm{NO}_{3}^{-}$ionic concentrations of Yaoundé groundwater range from: $0-4.32$ in the Wet season and $0.07-64.86$ in the Dry season. For the dry seasons the values are above the recommended value of $50 \mathrm{mg} / \mathrm{L}$ hazardous to infants. Soil/rock-water interactions can result to weathering and enrichment of the groundwater with ammonium ions, since groundwater quality is a function of the chemical composition of the soil/rock through which it passes. However rel- 
atively little of the nitrate found in natural waters is of mineral origin; most coming from organic and inorganic sources, the former including waste discharges and the latter comprising chiefly oxidation of ammonia from artificial agricultural fertilizer run-off. However, bacterial oxidation and fixing of nitrogen by plants can both produce nitrates. Interest is centered on nitrate concentrations for various reasons. Most importantly, high nitrate levels in waters to be used for drinking will render them hazardous to infants as they induce the "blue baby" syndrome (methaemoglobinaemia). The nitrate itself is not a direct toxicant but is a health hazard because of its conversion to nitrite which reacts with blood hemoglobin to cause methaemoglobinaemia.

The $\mathrm{Ca}, \mathrm{Mg}, \mathrm{Na}, \mathrm{K}, \mathrm{HCO}_{3}, \mathrm{Cl}$ and $\mathrm{SO}_{4}$ ionic concentrations show considerable seasonal variations. This is similar to results in the basement complex in Uganda imputing the variations to geology, climatic and hydrologic conditions (Nyende et al., 2014).

\subsubsection{Rock-Groundwater Interaction in Yaoundé}

To have an insight into the interaction between rock matrix and the groundwater in Yaoundé, a Gibb's diagram was used (Gibbs, 1970). Rock/mineral weathering, reverse/inverse ion-exchange, dissociation, and anthropogenic inputs are major solute acquisition mechanisms for the acquisition of major ions content in groundwater with respect to; atmospheric-precipitation, rock-weathering and evaporation-crystallization. This gives the controlling geochemical processes for the groundwater in Yaoundé.

Gibbs plot for Yaoundé Figure 12 and Table 7 indicate that: During the rainy season, for cations; 37 samples $82.2 \%$ are of rock-weathering dominance while 8 samples $17.8 \%$, are of atmospheric precipitation dominance. For anions; 33 samples $73.3 \%$ are of rock weathering dominance and 12 samples $26.7 \%$ are of the atmospheric precipitation dominance.

Table 7. Wet and Dry seasonal variations in rock/groundwater interaction from Gibbs diagram, Yaoundé.

\begin{tabular}{|c|c|c|c|c|}
\hline \multirow{2}{*}{$\begin{array}{c}\text { Gibbs Yaoundé } \\
\text { Ions }\end{array}$} & \multicolumn{2}{|c|}{ Wet season } & \multicolumn{2}{|c|}{ Dry season } \\
\hline & samples & $\%$ & Samples & $\%$ \\
\hline \multicolumn{5}{|l|}{ Cations } \\
\hline Atmospheric precipitation dominance & 7 & 16 & 8 & 18 \\
\hline Rock-weathering dominance & 38 & 84 & 37 & 82 \\
\hline \multicolumn{5}{|l|}{ Anions } \\
\hline Atmospheric precipitation dominance & 9 & 20 & 11 & 25 \\
\hline Rock-weathering dominance & 36 & 80 & 34 & 75 \\
\hline \multicolumn{5}{|l|}{ Cation + Anion } \\
\hline Atmospheric precipitation dominance & 16 & 17.8 & 19 & 21 \\
\hline Rock-weathering dominance & 74 & 82.2 & 63 & 79 \\
\hline
\end{tabular}




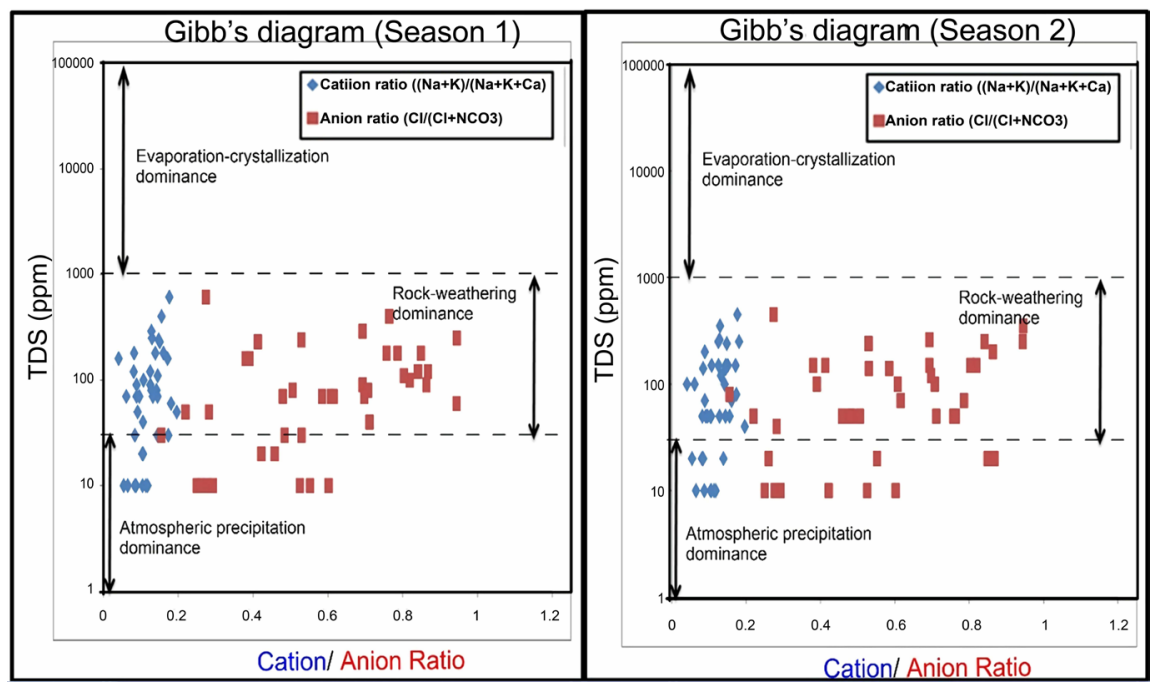

Figure 12. Plot of ionic ratio vs. TDS Yaoundé: Rainy season cations; 38 samples, $84 \%$ Rock-weathering dominance and 7 samples 16\% Atmospheric precipitation dominance. Dry season cations; 37 samples, $82 \%$ Rock-weathering dominance and 8 samples, $18 \%$ are of Atmospheric precipitation dominance. Rainy season anions; 36 samples, $80 \%$ are of Rock-weathering dominance and 9 samples, 20\% Atmospheric precipitation dominance. Dry season anions; 34 samples, 75\% are of Rock-weathering dominance and 11 samples, 25\% Atmospheric precipitation dominance (Gibbs, 1970).

During the dry season, for cations; 67 ions, 34 samples $73.3 \%$ rock weathering dominance and 23 ions 11 samples, $26.7 \%$ evaporation-crystallization dominance. For anions, 33 samples $73.3 \%$ are of rock weathering dominance and 12 samples $26.7 \%$ are of the atmospheric precipitation dominance.

Considering cations + anions, in the rainy season 70 ions, 35 samples $77.8 \%$ of the samples fall in the rock weathering dominance and while 20 ions, 10 samples $22.2 \%$ fall under atmospheric precipitation dominance. No sample fell under evaporation-crystallization dominance in both seasons. This reveals that, the weathering of the aquifer matrix is the primary dominant process in the acquisition of ions while atmospheric precipitation is the secondary process controlling the hydrogeochemistry in Yaoundé.

\subsubsection{Hydrogeochemical Character of Yaoundé Groundwater}

Durov diagram is a composite plot consisting of two ternary diagrams where the milliequivalent percentages of cations are plotted perpendicularly against those of anions (Durov, 1948); the sides of the triangles form a central rectangular binary plot of total cation vs. total anion concentrations. These are divided into nine Classes which give the hydrogeochemical processes determining the character of the water types in the aquiferous formation (Lloyd \& Heathcoat, 1985). Based on this Classification Table 8; three Classes occur in the rainy season; Class 1 recharging waters. 8 samples, 15.6\%; Class 2 ion exchange water. 10 samples, 22.2\%; Class 3 ion exchange water. 28 samples, 62.2\% respectively. Six Classes of occur in the dry season: Class 1 recharging waters. 19 samples, $42.2 \%$. Class 2 ion exchange water: 11 samples, 24.4\%; Class 3 ion exchange water: 11 
Table 8. Hydrogeochemical processes in groundwater using Durov's Diagram, Yaoundé (Lloyd and Heathcoat, 1985).

\begin{tabular}{|c|c|c|c|c|c|}
\hline \multirow{2}{*}{ SN } & \multirow{2}{*}{$\begin{array}{c}\text { Durov's Diagram Yaoundé } \\
\text { Water type and hydrogeochemical process }\end{array}$} & \multicolumn{2}{|c|}{ No. } & \multicolumn{2}{|c|}{$\%$} \\
\hline & & Wet & Dry & Wet & Dry \\
\hline 1 & $\mathrm{HCO}_{3}^{-}$and $\mathrm{Ca}^{+}$dominant, indicates recharging waters in migmatites and gneiss. & 8 & 19 & 15.6 & 42.2 \\
\hline 2 & $\begin{array}{l}\text { This water type is dominated by } \mathrm{Ca}^{+} \text {and } \mathrm{HCO}_{3}^{-} \text {ions. Association with dolomite is presumed if } \mathrm{Mg}^{+} \\
\text {is significant. However, those samples in which } \mathrm{Na}^{+} \text {is significant, an important ion exchange is } \\
\text { presumed }\end{array}$ & 10 & 11 & 22.2 & 24.4 \\
\hline 3 & $\begin{array}{l}\mathrm{HCO}_{3}^{-} \text {and } \mathrm{Na}^{+} \text {are dominant, normally indicates ion exchanged water, although the generation of } \\
\mathrm{CO}_{2} \text { at depth can produce } \mathrm{HCO}_{3}^{-} \text {where } \mathrm{Na}^{+} \text {is dominant under certain circumstances }\end{array}$ & 28 & 11 & 62.2 & 24.4 \\
\hline 4 & $\begin{array}{l}\mathrm{SO}_{4}^{2-} \text { dominates, or anion discriminant and } \mathrm{Ca}^{+} \text {dominant, } \mathrm{Ca}^{+} \text {and } \mathrm{SO}_{4}^{2-} \text { dominant, frequently } \\
\text { indicates recharge water in lava and gypsiferous deposits, otherwise mixed water or water exhibiting } \\
\text { simple dissolution may be indicated. }\end{array}$ & 0 & 2 & 0 & 4.4 \\
\hline 5 & No dominant anion or cation, indicates water exhibiting simple dissolution or mixing & 0 & 1 & 0 & 2.2 \\
\hline 6 & $\begin{array}{l}\mathrm{SO}_{4}^{2-} \text { dominant or anion discriminate and } \mathrm{Na}^{+} \text {dominant; This water type is not frequently } \\
\text { encountered and indicates probable mixing or uncommon dissolution influences. }\end{array}$ & 0 & 1 & 0 & 2.2 \\
\hline
\end{tabular}

samples, 24.4\%; Class 4 simple dissolution: 2 samples, 4.4\%; Class 5 simple dissolution or mixing: 1 sample, $2.2 \%$; Class 6 probable mixing or uncommon dissolution influences: 1 sample, 2.2\% respectively. There are no Classes 5 - 9 in the rainy season and no Classes 7 - 9 in the dry season samples in groundwater from Yaoundé Figure 13. In the rainy season, fresh recently recharging water exchanges ions with the matrix of the formation, while simple dissolution or mixing also goes on between the recently recharging and the existing groundwater in the formation. In the dry season, recharging groundwater having spent more time in the formation continues to exchange ions to a lesser extent with the matrix of the formation while increasingly; simple dissolution or mixing also goes on between the recently recharging groundwater and the pre-existing groundwater in the formation, piston flow. The absence of samples showing $\mathrm{Na}^{+}$and $\mathrm{Cl}^{-}$as dominant cation/anion, no Classes 5 - 9 in the rainy season and no Classes 7 - 9 in the dry season, indicates that the groundwater in Yaoundé is not related to reverse or inverse ion exchange of $\mathrm{NaCl}$ waters or any end-point down gradient waters.

\subsubsection{Groundwater Types Occurring in Yaoundé}

In saturated formations; aquifers, groundwater occurs in varied chemical modes associated ionic complexes that differ in their chemical composition as a function of; lithology, ionic content, solution kinetics and flow patterns called hydrogeochemical facies (Todd, 1980). Hydrogeochemical facies, water types and the geochemical evolution of the ionic content of groundwater is elucidated by plotting water sample's laboratory analysis results on Piper's trilinear diagram (Piper, 1944). In Figure 14, the cation-field has; Calcium-rich waters; 34 samples, $75.6 \%$ in the rainy and 22 samples, $48.8 \%$ in the dry season. Magnesium-rich waters: 11 samples, $24.4 \%$ in the rainy and 23 samples, $51.1 \%$ in the dry seasons. Bicarbonate-rich waters: 35 samples, $77.8 \%$ and 17 samples, $37.8 \%$ in the rainy 

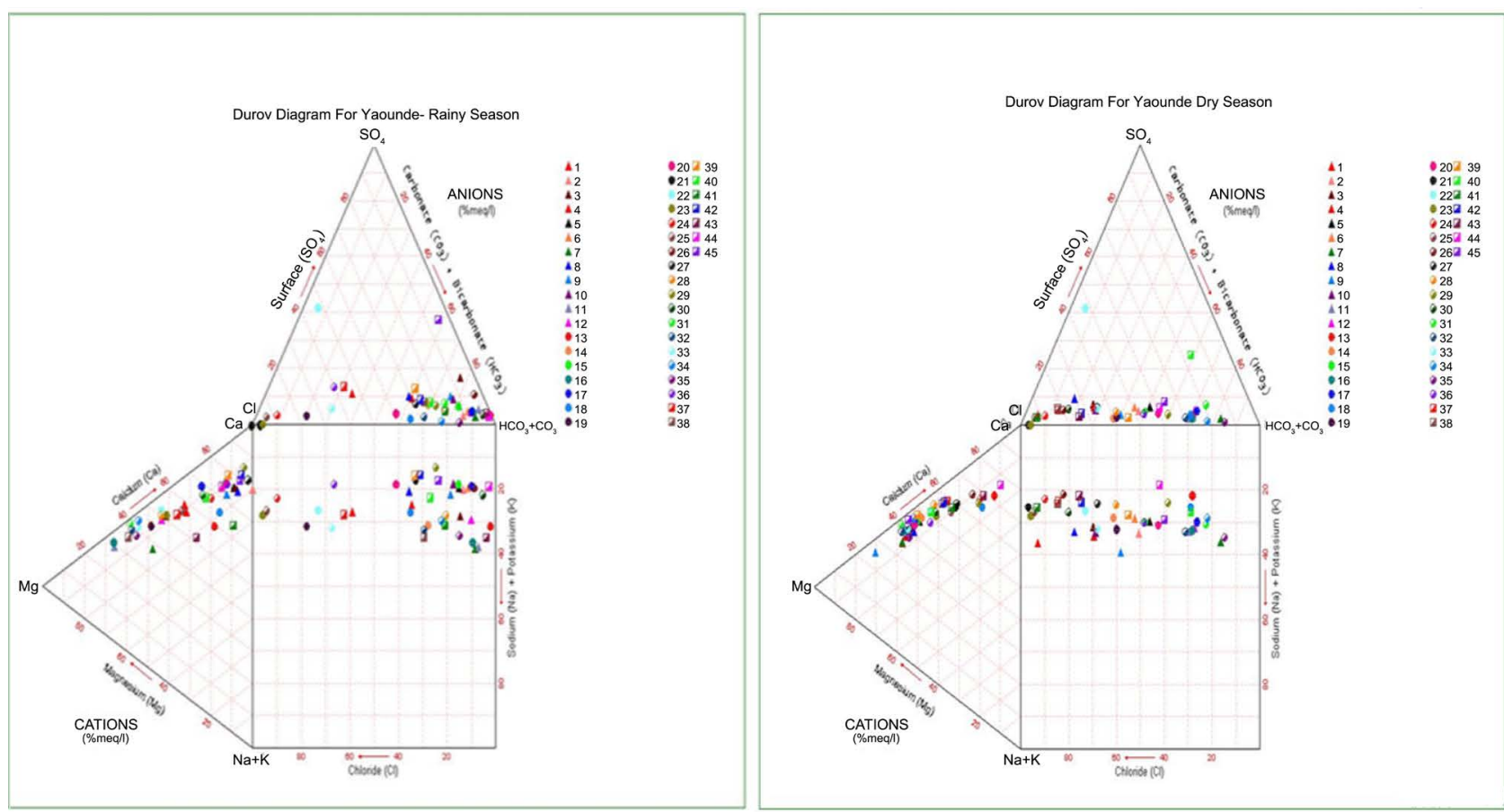

Figure 13. Durov plot of Yaoundé groundwater for the processes in groundwater evolution; for rainy season; recharge, 8 samples, $17.78 \%$; ion exchange, 37 samples, $82.22 \%$ while in the dry season; recharge, 19 samples, $42.2 \%$; ion exchange, 22 samples, $48.8 \%$; simple dissolution or mixing, 4 samples, 8.8\% (Durov, 1948; Lloyd \& Heathcoat, 1985).
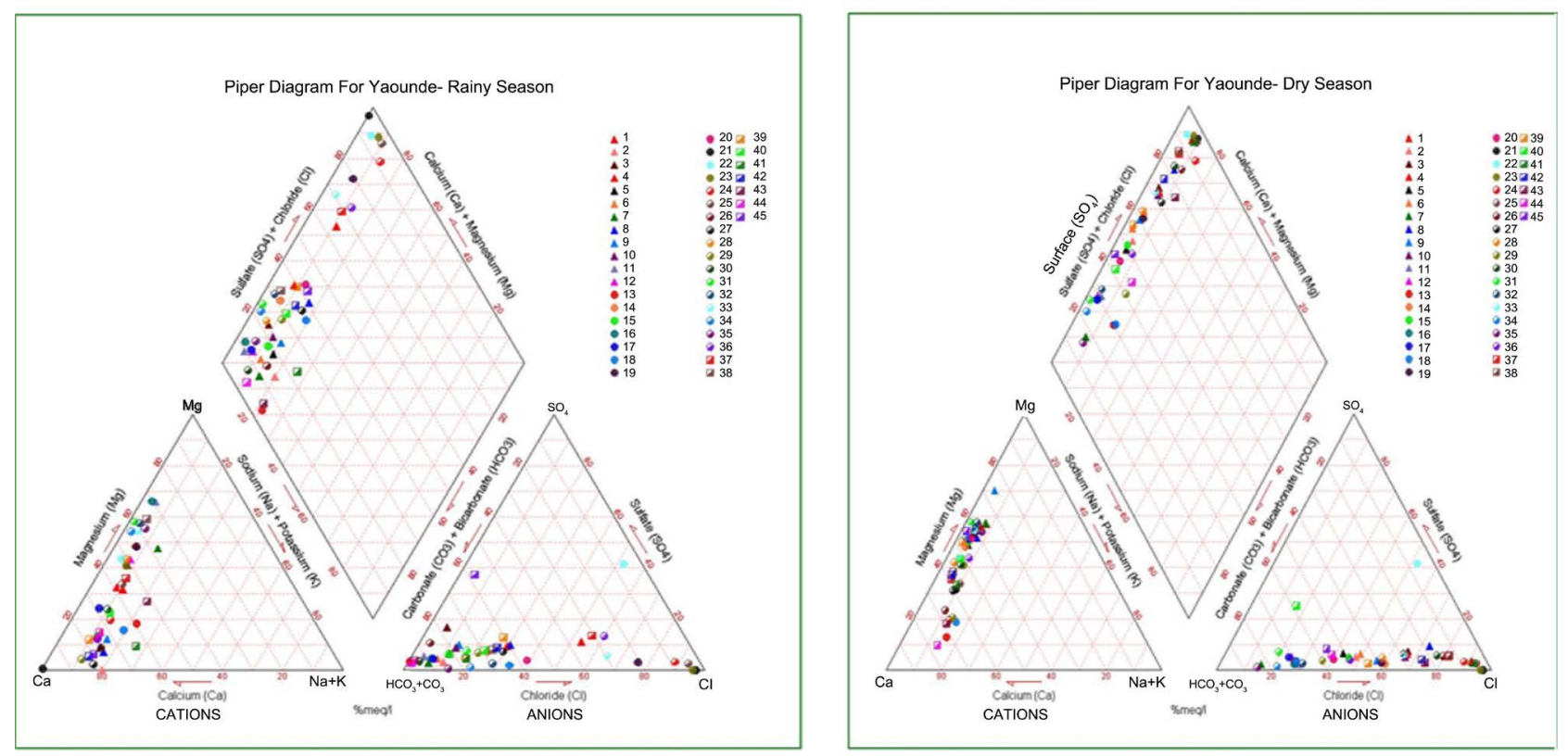

Figure 14. Piper's diagram for Yaoundé groundwater; Diamond field (I): Ca-Mg-Cl-SO $\mathrm{S}_{4}$ hydrogeochemical facies has 10 samples, $22.2 \%$ in the rainy and 16 samples, $35.6 \%$ in the dry season. Field (IV), Ca-Mg-HCO hydrogeochemical facies has 35 samples, $77.8 \%$ in the rainy and 29 samples, $64.4 \%$ in the dry season. No samples plotted on field II and field III (Langguth, 1996).

season. Chloride-rich water: 10 samples $22.2 \%$ in the rainy and 28 samples, $62.2 \%$ in dry season. The dominance of Calcium bicarbonate and Magnesium bicarbonate waters types in both seasons indicate freshly recharged groundwater 
that has not moved a long distance from its source (Hounslow, 1995).

\subsubsection{Hydrogeochemical Facies and Water Types Occurring in Yaoundé}

\section{1) Piper's Hydrogeochemical facies}

From the Piper's diagram, Field (I): $\mathrm{Ca}-\mathrm{Mg}-\mathrm{Cl}-\mathrm{SO}_{4}$ hydrogeochemical facies has 10 samples, $22.2 \%$ in the rainy and 16 samples, $35.6 \%$ in the dry season. This facies is characteristic of stagnant groundwater zones or of groundwater at some distance along its flow path (Eelco 2014). Field (IV), Ca-Mg- $\mathrm{HCO}_{3}$ hydrogeochemical facies has 35 samples, $77.8 \%$ in the rainy and 29 samples, $64.4 \%$ in the dry season. This facies is characteristic of freshly recharged groundwater that has equilibrated with $\mathrm{CO}_{2}$ and soluble carbonate minerals under an open system conditions in the vadose zone typical of shallow groundwater flow systems in crystalline phreatic aquifers.

No samples plotted on Field II and Field III. The high contribution of alkaline earth elements $77.8 \%$ in the rainy season and $64.4 \%$ in the dry season may be due to direct ion-exchange processes which enrich groundwater with alkaline earth elements. The dominance of $\mathrm{Ca}-\mathrm{Mg}-\mathrm{HCO}_{3}$ hydrogeochemical facies in this area could be due to dissolution of gases and minerals, particularly $\mathrm{CO}_{2}$ and $\mathrm{CO}_{2}$-related compounds from the atmosphere dissolved in precipitation and during groundwater infiltration through the vadose zone.

\section{2) Piper-Langguth groundwater types}

The diamond field of piper diagram has further been divided into seven fields Classifying water types and designated with alphabets from A to G (Langguth, 1996). Using this Classification, the water from the study area is distinguished into the A, B, and C categories (Table 9). The D, E, F, and G water types are absent. In the rainy season; Category A, 32 samples, $64.4 \%$; characterized by normal

Table 9. Seasonal variations in groundwater types from Piper's trilinear diagram, Yaoundé (Langguth, 1996).

\begin{tabular}{|c|c|c|c|c|c|}
\hline & \multirow{2}{*}{$\begin{array}{c}\text { Yaoundé Durov's } \\
\text { Water type }\end{array}$} & \multicolumn{2}{|c|}{ samples } & \multicolumn{2}{|c|}{$\%$} \\
\hline SI & & Wet & Dry & Wet & Dry \\
\hline \multicolumn{6}{|c|}{ Diamond Field } \\
\hline A & Normal earth alkaline water; prevailing $\mathrm{HCO}_{3}^{-}$ & 29 & 10 & 64.4 & 22.2 \\
\hline B & Normal earth alkaline water; prevailing $\mathrm{HCO}_{3}^{-}, \mathrm{SO}_{4}^{2-}$ or $\mathrm{Cl}^{-}$ & 2 & 12 & 4.4 & 26.7 \\
\hline C & Normal earth alkaline water; prevailing $\mathrm{SO}_{4}^{2-}$ or $\mathrm{Cl}^{-}$ & 10 & 23 & 22.2 & 51.1 \\
\hline D & Earth alkaline water; increased portions of alkalis; prevailing $\mathrm{HCO}_{3}^{-}$ & 4 & 0 & 8.9 & 0 \\
\hline \multicolumn{6}{|c|}{ Cation Field } \\
\hline 1 & Ca-rich waters & 33 & 19 & 73.3 & 42.2 \\
\hline 2 & Mg-rich waters & 12 & 26 & 26.7 & 57.8 \\
\hline \multicolumn{6}{|c|}{ Anion Field } \\
\hline 4 & $\mathrm{HCO}_{3}^{-}$waters & 37 & 17 & 82.2 & 37.8 \\
\hline 6 & $\mathrm{Cl}^{-}$waters & 8 & 28 & 17.8 & 62.2 \\
\hline
\end{tabular}


earth alkaline water with prevailing bicarbonate. Category B; 3 samples, $4.4 \%$ are characterized by normal earth alkaline water with prevailing sulfate or chloride and Category C; 10 samples, $22.2 \%$ are characterized by alkaline earth water with increased portions of alkalis with prevailing bicarbonate. In the dry season: Category A; 11 samples, 22.2\%; Category B, 11 samples, 22.2\% and Category C; 23 samples, $51.1 \%$. The dominant water types are Category A, 64.4\%; Normal earth alkaline water; prevailing $\mathrm{HCO}_{3}^{-}$in the rainy season and Category $\mathrm{C}, 51.1 \%$; Normal earth alkaline water; prevailing $\mathrm{SO}_{4}^{2-}$ or $\mathrm{Cl}^{-}$in the dry season. This groundwater has a modern age and is being rapidly recharged by precipitation.

\subsection{Water Quality}

\subsubsection{Water Quality for Drinking Purposes}

In urban and semi urban slums and some rural areas in Cameroon, groundwater sources in the form of dugwells or borewells are the only source for drinking water. In the present study, to ascertain whether or not the groundwater in use by the population of the capital city in Cameroon meets the chemical water quality guidelines, the following water quality parameters are determined (WHO, 2017).

1) Water Quality Index WQI

The WHO permissible values of ions present in the groundwater have been used to calculate WQI values (Pradhan et al., 1998; Asadi et al., 2007). For the rainy season 43 samples, 95.6\% have WQI 0 - 25; Excellent. 2 samples, $4.4 \%$ have WQI 26 - 50; Good, while in the dry season; 15 samples, 33.3\% have WQI 0 - 25; excellent. 9 samples, 20\% have WQI 26 - 50; Good; 8 samples, 17.7\% have WQI 51 - 75 poor; 7 samples, 15.5\% have WQI 76 - 100; very poor and 6 samples, 13.3\% have WQI > 100; unsuitable Figure 15 .

\section{2) Total Hardness}

During the rainy season total hardness (TH) ranges between 1.00 to 17.00 $\mathrm{mg} / \mathrm{L}$ with an average of $8.36 \mathrm{mg} / \mathrm{L}$, and during dry season, it ranges between 0.50 to $11.00 \mathrm{mg} / \mathrm{L}$ with an average of $6.82 \mathrm{mg} / \mathrm{L}$. All the $45(100 \%)$ groundwater samples for both seasons are $(<50 \mathrm{mg} / \mathrm{L})$ soft. The total hardness $(\mathrm{TH})$ of water is a measure of mainly calcium carbonate and magnesium carbonate dissolved in

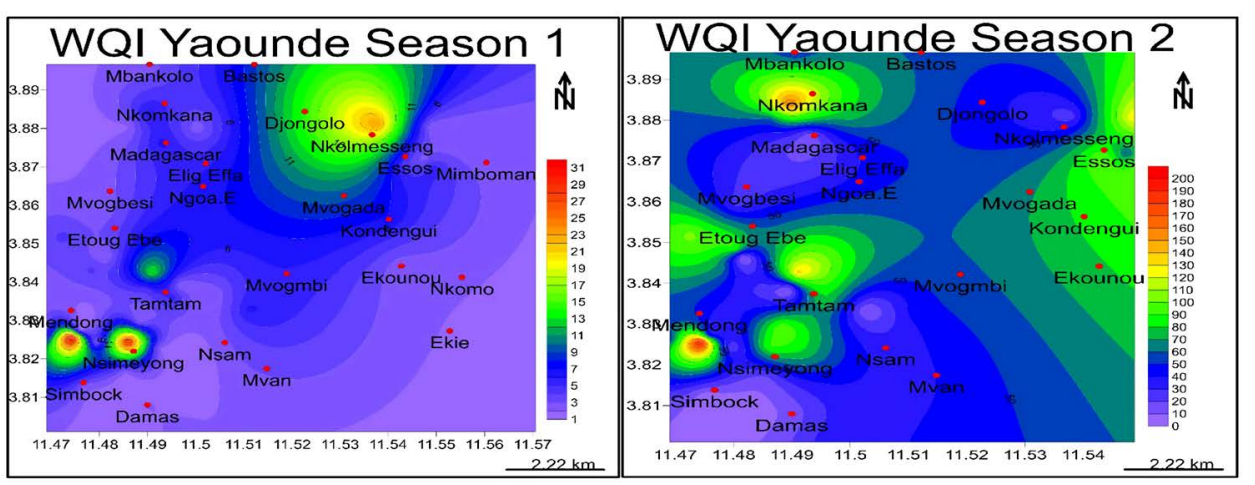

Figure 15. Water Quality Index (WQI) Classification for Yaoundé groundwater; in the wet seasonhigh values occur at Nkolmesseng, Mendong and Nsimeyong while in the dry season at Nkomkana and Nsimeyong. 
groundwater. The general acceptance level of hardness is $300 \mathrm{mg} / \mathrm{L}$, although WHO has set an allowable limit of $600 \mathrm{mg} / \mathrm{L}$ (Figure 16). Water hardness has no known adverse effects; however, some evidence indicates its role in heart disease. Hard water is unsuitable for domestic use and it is a measure of the $\mathrm{Ca}^{2+}$ and $\mathrm{Mg}^{2+}$ content expressed in equivalent of calcium carbonate (WHO, 2017).

\subsubsection{Water Quality for Agro-Industrial Perposes}

To assess the overall irrigational water quality of the samples collected, six computed water quality parameters have been considered; namely, Sodium Percentage (SSP), Sodium Adsorption Ratio (SAR), Soluble Permeability Index (P.I.), Residual Sodium Carbonate (RSC), Magnesium Adsorption Ratio and Kelly's Ratio.

\section{1) Sodium Adsorption Ratio (SAR)}

SAR values are plotted against EC values (in $\mu S / \mathrm{cm}$ ) on the U.S. Salinity diagram to categorize analysed water samples according to their irrigational suitability quotient. SAR values range from $0.005-0.075$ in rainy seasons and 0.01 0.14 during Dry season Figure 17. Based on the SAR values, all samples have low sodium hazard and on plotting over the USSL Salinity diagram Figure 11 all the 45 samples (100\%) fall in the $S_{1}-C_{0}, S_{1}-C_{1}, S_{1}-C_{2}, S_{1}-C_{3}$ Classes for both rainy season and dry season considered suitable for irrigation.

\section{2) Soluble Sodium Percentage (SSP) or $\mathrm{Na} \%$}

Soluble Sodium Percentage (SSP) is used to evaluate sodium hazard. SSP values range from $1.50 \%-15.00 \%$ in rainy season and $3.00 \%-26 \%$ during the dry season. Water with a SSP greater than $60 \%$ can result in sodium accumulations that will cause a breakdown in the soil's physical properties Figure 18 (Khodapanah et al., 2009). The SSP values and the EC values have been plotted on the Wilcox diagram Figure 19 to give sodium hazard Classification. In the rainy season 42 samples (93.3\%) fall under Class I "Excellent to good" and in Class II, 3 samples (6.7\%) "Good to Permissible" while during the dry season 44 samples (97.8\%) Class I "Excellent to good" and 01 sample (2.2\%) in Class II "Good to Permissible" respectively. High sodium ion concentration in soil can take a toll

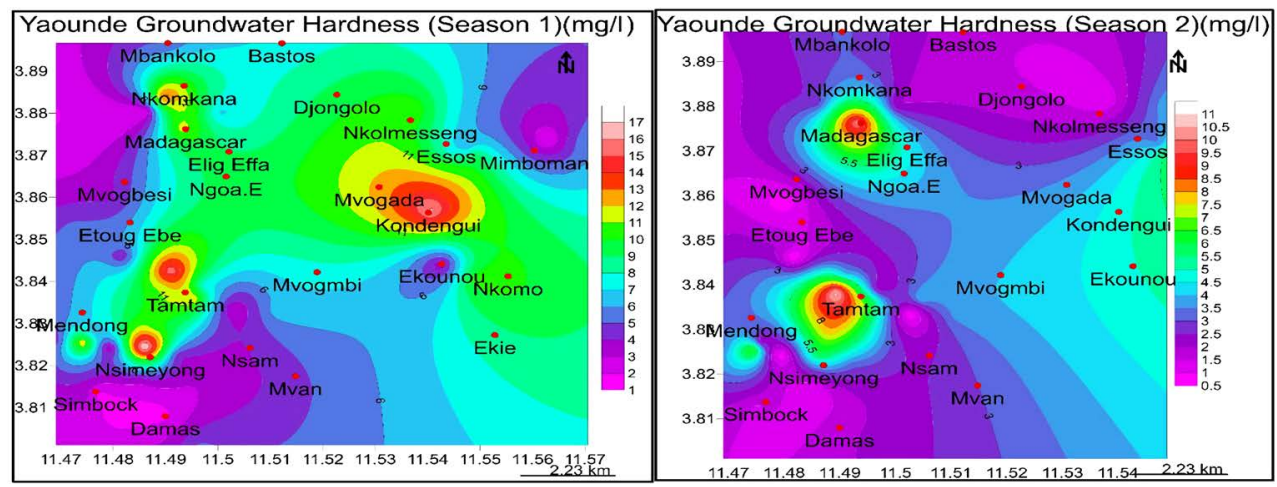

Figure 16. Total hardness TH of groundwater in Yaoundé; in the wet seasonhigh values occur at Nkomkana, Kondengi, Tamtam, and Nsimeyong while in the dry season at Madagasca rand Tamtam. 


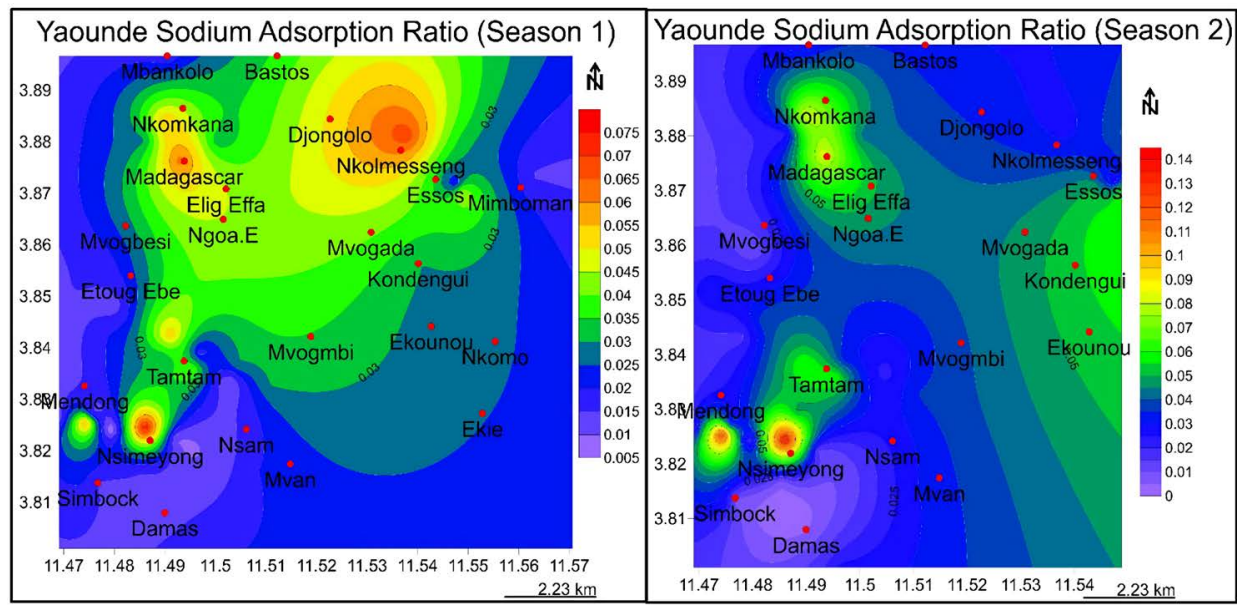

Figure 17. SAR values for groundwater in Yaoundé; rainy season values in the wet season high values occur at Madagascar, Nkolmesseng and Nsimeyong, while in the dry season at Nsimeyong, and Mendong.

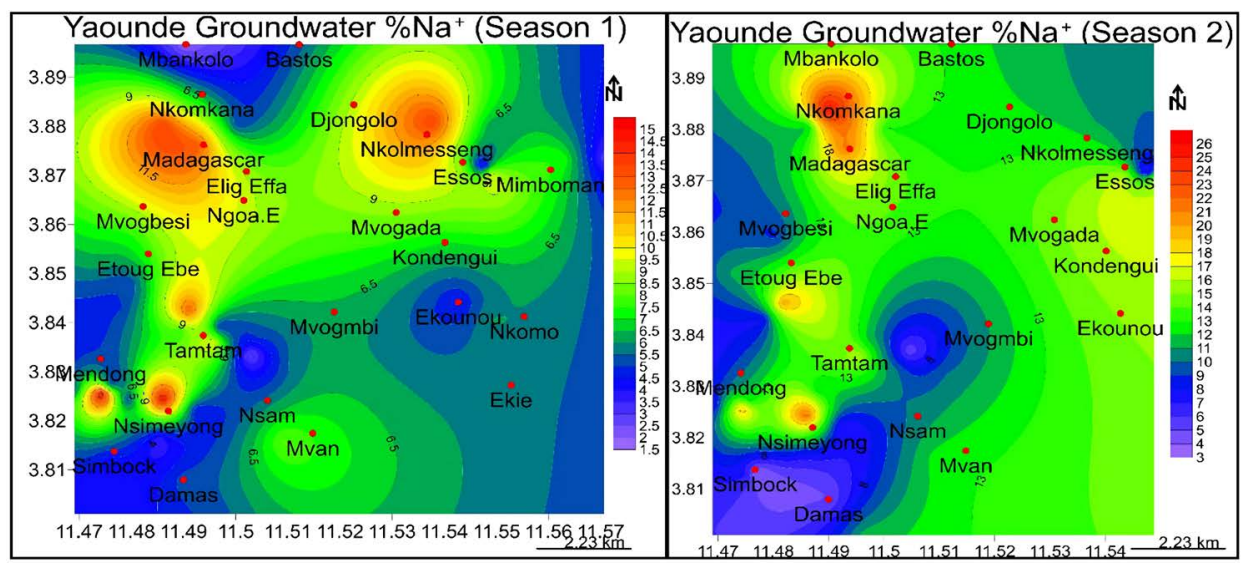

Figure 18. Sodium per cent ( $\mathrm{Na} \%$ ) of Yaoundé groundwater; in the wet season high values occur at Madagascar, Nkolmesseng, Nsimeyong and Mendong, while in the dry season at Nsimeyong, Etoug-Ebe, Madagascar and Nkomkana.

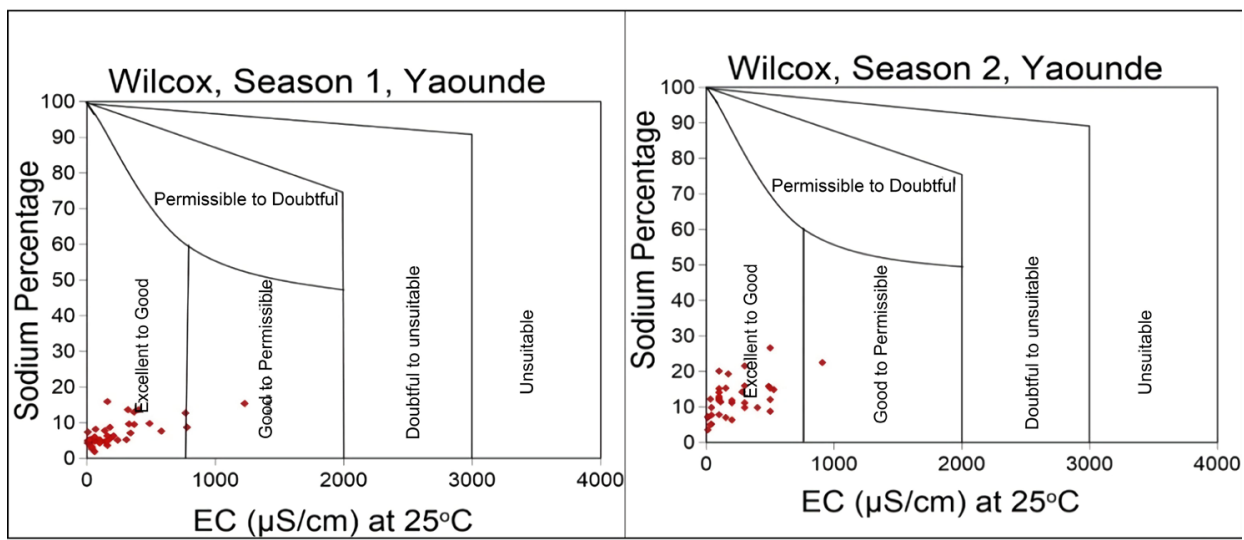

Figure 19. Wilcox plot of $\mathrm{Na} \%$ vs. EC for groundwater in Yaoundé; in the rainy season 42 samples, 93.3 \% is in Class I "Excellent to good" and in Class II; 3 samples, 6.7\% "Good to Permissible" while in the dry season 44 samples, $97.8 \%$ Class I "Excellent to good" and 01 sample, $2.2 \%$ in Class II "Good to Permissible" for irrigation. 
on internal drainage patterns in soil as release of calcium and magnesium ions are facilitated due to absorption of sodium by clay particles.

\section{3) Permeability Index (PI)}

The soil permeability of an area eventually decreases due to continuous irrigational practices and is defined based on quantity of bicarbonate, sodium, calcium and magnesium in water an empirical index termed, "Permeability Index" (Doneen, 1964). Permeability index in Yaoundé Figure 20 varies from 4.00 Nkomo 250.00 Simbok in rainy season and from 12.00 Nkomo - 440.00 Nsimeyong in dry season. Using the FAO Classification based on the PI; in the rainy season, 3 samples, $7 \%$ are Class I, excellent; 36 samples, $80 \%$ are in Class II; Good and 6 samples, $13 \%$ are in Class III; unsuitable while during the dry season, No sample was in Class I, 40 samples, $88.9 \%$ are in Class II; Good, and 5 samples (11.1\%) are in Class III; unsuitable Figure 21.

\section{4) Residual Sodium Carbonate (RSC)}

Residual sodium carbonate (RSC) index of irrigation soil water indicates the alkalinity hazard of a soil. In Yaoundé, groundwater RSC values range between 0.5 Simbok - 1.75 Nkondengi in the rainy season and 0.25 Mvogbesi, Nsimeyong - 1.45 Tamtam, Madagascar in the dry season. In the rainy season, 42 samples 93.4\% have RSC < 1.25; Good, 2 samples (4.4\%) have RSC > 1.25 - $2.5<$; Doubtfuland 1 sample $(2.2 \%)$ has RSC $>2.5$; Unsuitable (Figure 23). In the dry season; 44 samples (97.8\%) have RSC $<1.25$; Good and 1 sample (2.2\%) has RSC $>1.25$ - 2.5<; Doubtful (Figure 22). That $93.4 \%$ and $97.8 \%$ of the water samples have RSC $<1.25$ in both seasons indicates groundwater in this area poses no alkaline hazard to the soil in both dry and wet seasons. Only $2.2 \%$ in the rainy season represents localised hazards. RSC index is used to find water suitability of for irrigation in clayey soils which has high cation exchange capacity. When dissolved sodium in comparison with dissolved calcium and magnesium is high in water, clay soils swell or undergo dispersion which drastically reduces infiltration capacity.

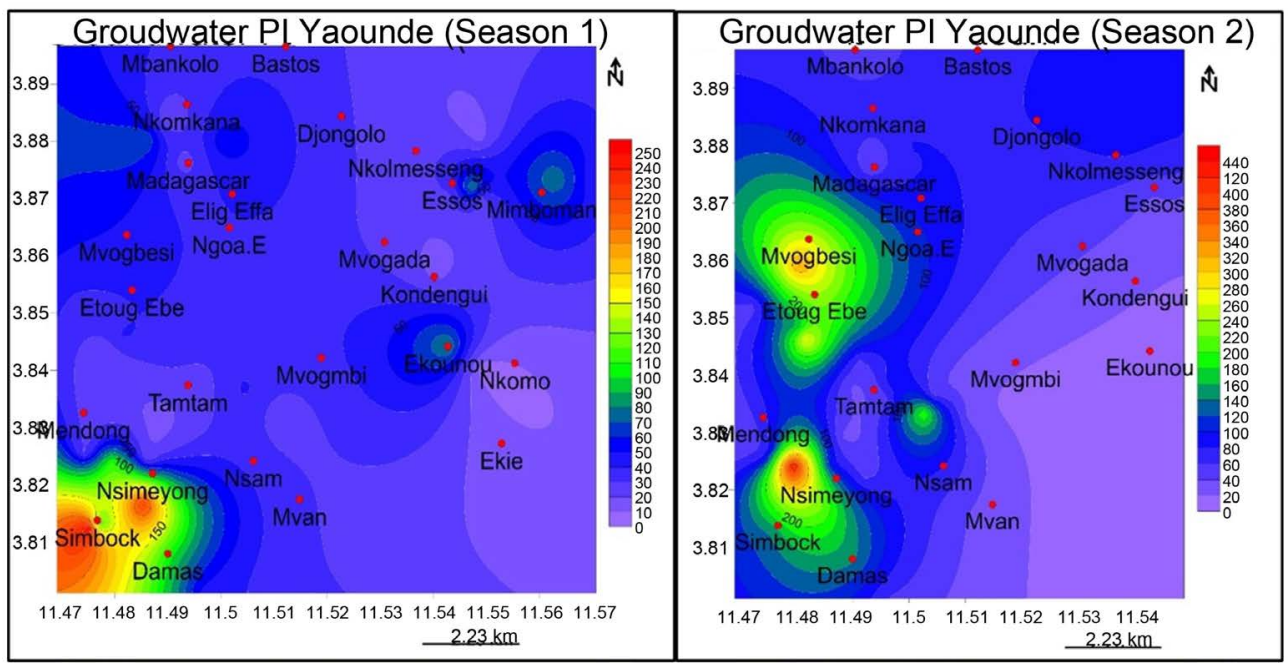

Figure 20. Permeability Index for groundwater in Yaoundé; in rainy season is from 4.00 (Nkomo) - 250.00 (Simbok) and in the dry season from 12.00 (Nkomo) - 440.00 (Nsimeyong). 


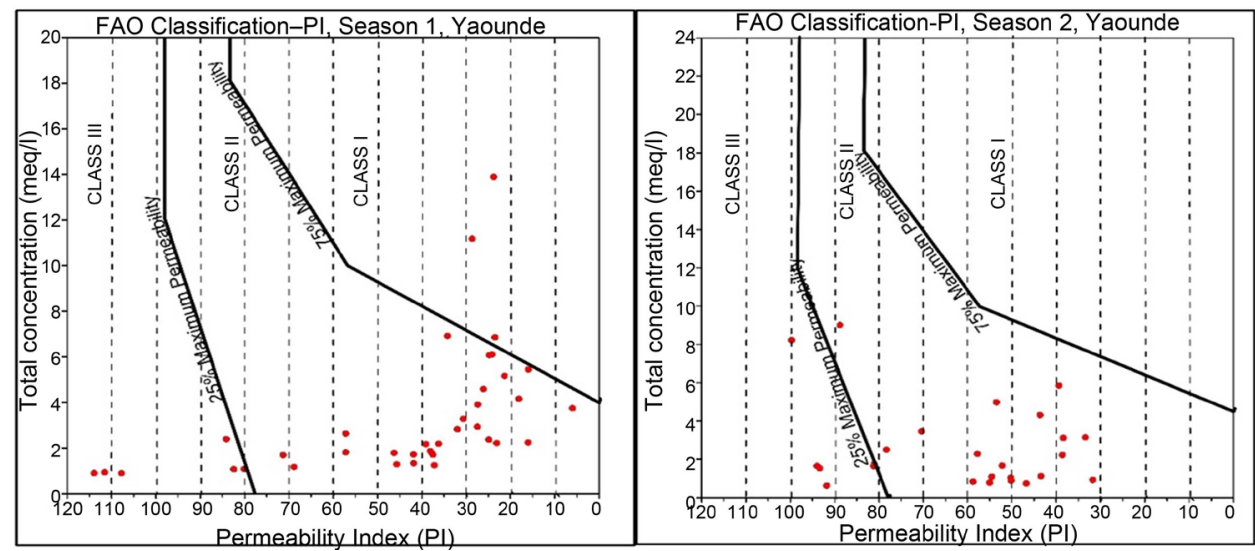

Figure 21. FAO Classification of groundwater in Yaoundé; during the rainy season1, 3 samples, 7\% are Class I, excellent; 36 samples, $80 \%$ are in Class II; Good and 6 samples, $13 \%$ are in Class III; unsuitable. In the dry season2, No sample is in Class I, 40 samples, $88.9 \%$ are in Class II; Good, and 5 samples, $11.1 \%$ are in Class III; unsuitable.

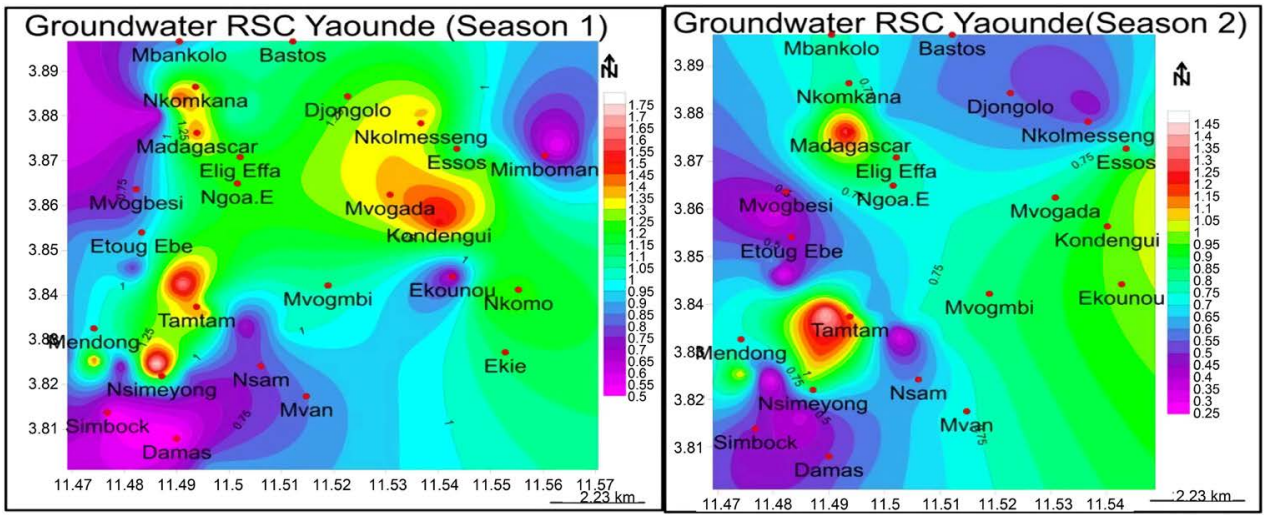

Figure 22. Residual Sodium Carbonate RSC; in the rainy season, values range from 0.5 (Simbok) - 1.75 (Nkondengi) and in the dry season 0.25 (Mvogbesi, Nsimeyong) - 1.45 (Tamtam, Madagascar).

\section{5) Magnesium Adsorption Ratio (MAR)}

MAR categorizes water into two broad Classes: water having MAR $<50$ considered suitable for irrigation and MAR $>50$ considered unsuitable (Paliwal, 1972). In the rainy season in Yaoundé, 25 samples (56\%) are <50; suitable and 20 samples $(44 \%)>50$ are unsuitable. In the dry season, 33 samples $(73 \%)$ are $<50$; suitable and 12 samples $(27 \%)>50$ are unsuitable Figure 23. In the dry season, $73 \%$ of the samples have MAR values suitable for irrigation. During the rainy season, the MAR values change rendering about almost half of the samples unsuitable for irrigation. Generally in most groundwater $\mathrm{Ca}^{2+}$ and $\mathrm{Mg}^{2+}$ maintain a state of equilibrium (Hem, 1985). During equilibrium more $\mathrm{Mg}^{2+}$ in groundwater adversely affects the soil quality rendering it alkaline which result in decrease of crop yield (Giggenbach, 1988).

\section{6) Kelly's Ratio (KR)}

This is ratio is of sodium ion concentration over calcium and magnesium ion concentrations (Kelly, 1963). KR $<1$ is considered suitable for irrigation and 


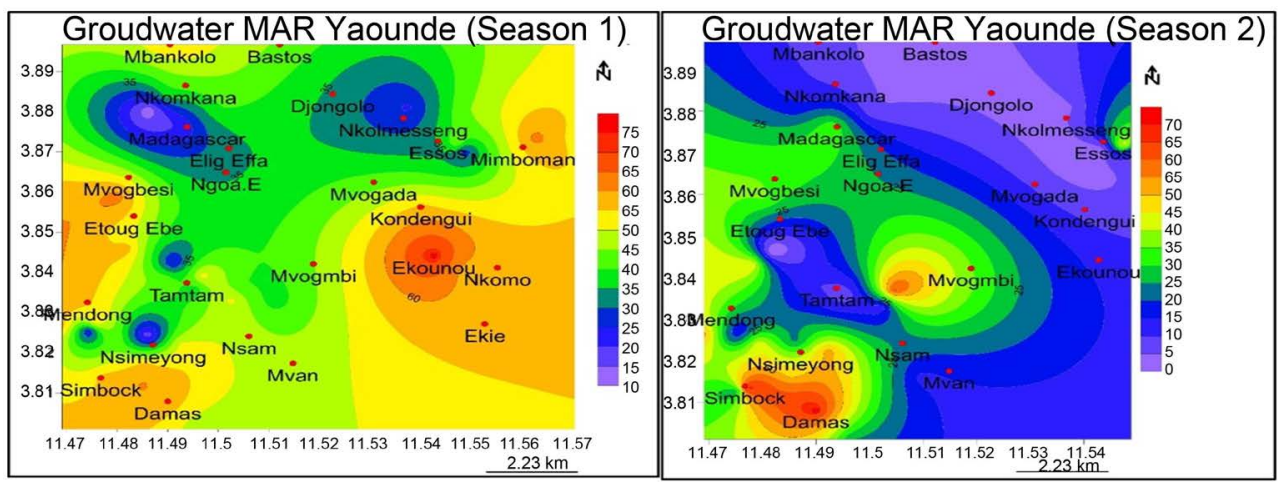

Figure 23. Magnesium Adsorption Ratio MAR of Yaoundé groundwater; in the wet season high values occur at Ekounou, Mimbomann, while in the dry season at Simbok, Damas and Mvogmbi.

$\mathrm{KR}>1$ is unsuitable. During rainy season, KR values vary between $0.003-0.026$ and during the dry season the values vary between 0.005 - 0.07 (Figure 24). All 45 samples, $100 \%$ in Yaoundé were suitable for irrigation for both seasons.

\subsection{Aquifer Setting}

From field observations, borehole lithostratigraphic sections and by comparing various case studies in similar terrain in gneiss-type rocks and in some parts of Yaoundé have indicated that topography controls groundwater flow and that base flow to rivers is an important factor moderating groundwater movement in Yaoundé as shown here by the groundwater contours for four seasons (Teikeu et al., 2016; Wyns et al., 2004; Clark, 1985; Acworth, 1987; Obiefuna \& Sheriff, 2011; Fouépé Takounjou et al., 2012). Lithologies from their VES curves corroborated the lithologs of boreholes from this area (Teikeu et al., 2012). Some researchers have concluded with a dual aquifer conceptual model for fractured rock gneiss aquifers (Teikeu et al., 2012; Wyns et al., 2004). Although weathered gneiss terrains are layered, aquifer models suitable for sedimentary terrains of layered formations cannot apply here where the fissures and fractures cut across the layering in the formations' regolith that still retain relics of the continuous gneiss fractures and fissures intact in saprolite, weathered basement and fresh fractured basement. Similar weathering and erosional processes induce similar geological structures and that at catchment scale for water resources applications, the fresh basement is considered as impermeable; of very low storativity and that in highly foliated rocks (i.e., gneisses or schists) the orientation of the fissures is controlled by the rock structure (Dewandel et al., 2006). Also, fissured layers assume storage functions in composite aquifers with the fresh basement being permeable only locally, where tectonic fractures are present (Wyns et al., 2004). This depends to a large extent on the density of fractures (the number of fissures/fractures per unit area). At high density shear zones as in Yaoundé; these rocks could store huge reserves of groundwater in the fractures and fissures.

As a consequence of the hydrogeochemical analysis above, a modified hydrogeological conceptual model of weathered migmatite/gneiss-type aquifer in Yaoundé is proposed (Figure 25). 


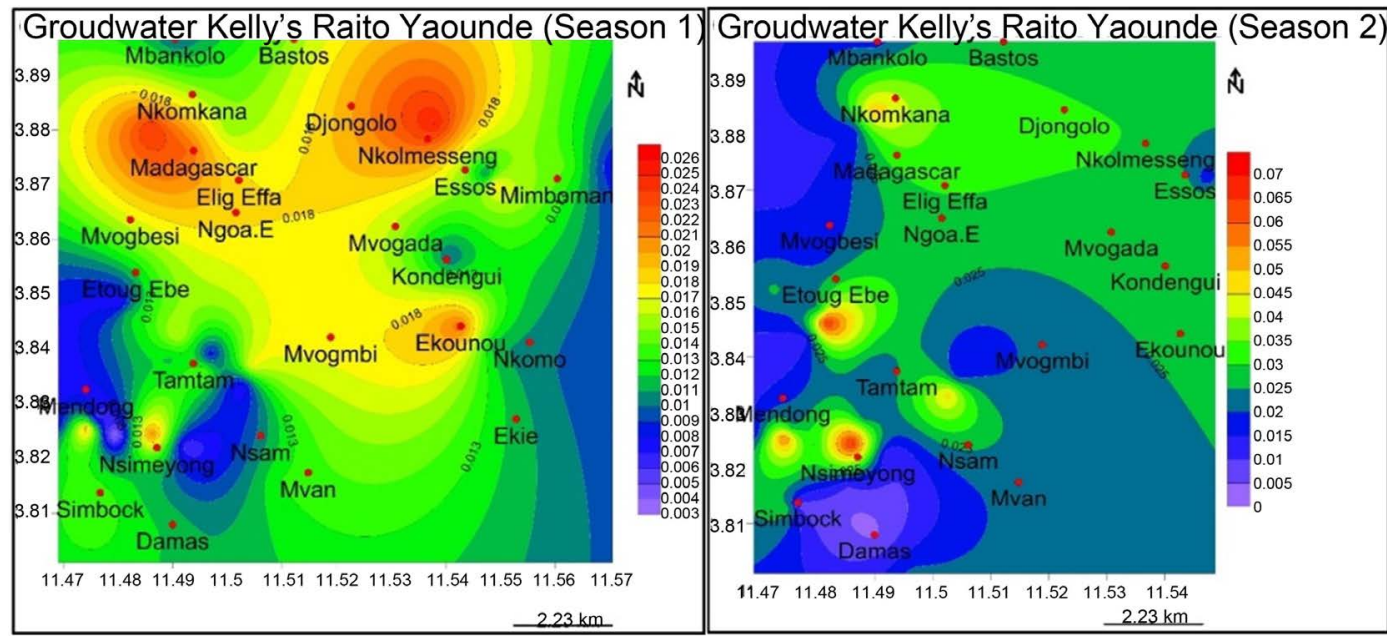

Figure 24. Kelly's Ratio KR for groundwater in Yaoundé; during rainy season, values are 0.003 - 0.026 and during the dry season 0.005 Damas - 0.07 EtougEbe. All 45\% samples, 100 are $<1$, suitable for irrigation for both seasons.

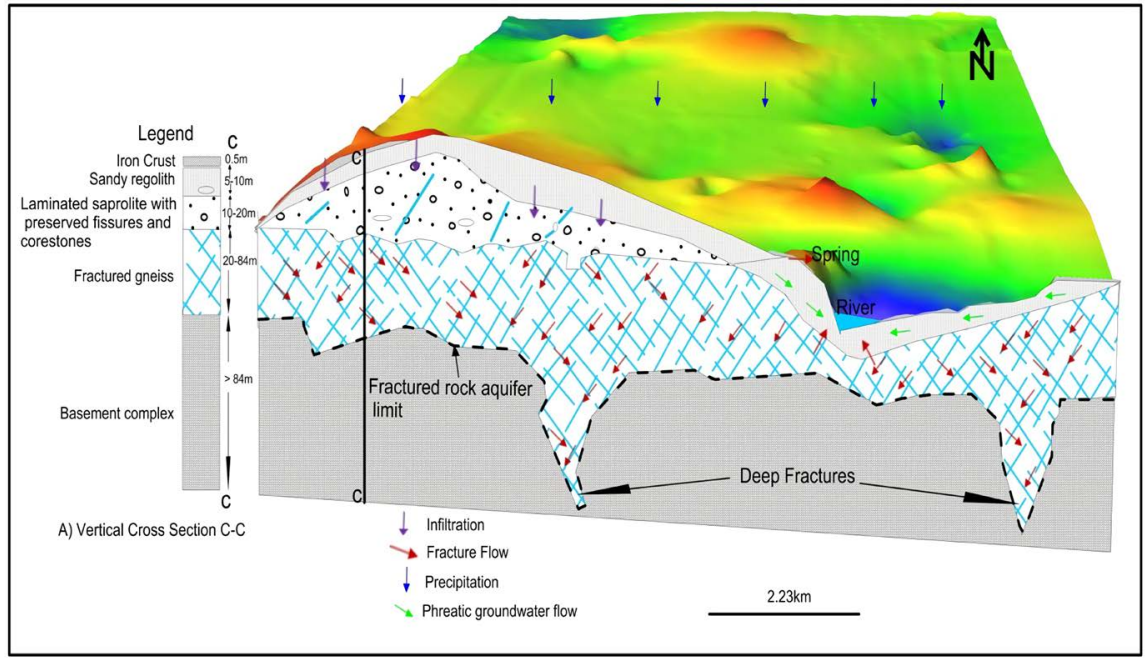

Figure 25. Modified hydrogeological conceptual model of weathered migmatite/gneiss-type aquifer in Yaoundé

In this model, precipitation infiltrates and flows through;

1) Sandy clayey weathered basement regolith (with relics of fissures and fractures)

2) Fractured/fissured unweathered basement

3) Deep large regional fractures with larger flow volumes.

Groundwater is stored in;

1) The fracture/fissure insular network infrastructure of unconnected joints, fissures and fractures; the phreatic local subsystem with only limited local storage and can only supply dugwells in the wet seasons. Here storage is directly impacted by seasonal variations in precipitation.

2) The fracture/fissure network infrastructure of connected joints, fissures and fractures; the intermediate subsystem. Here only intermediate flow and storage 
takes place with limited connection to the regional subsystem which could supply dugwells throughout the year and low discharge borewells in the rainy season.

3) The fracture/fissure interconnected network infrastructure which also serves as the major conduit/channel for storage and flow of groundwater; the Regional subsystem. Here groundwater is stored (channel storage) and flows throughout the region through interconnected fracture/fissure networks that can supply large discharge borewells.

Groundwater contours are concentric around areas of high elevation and mimic the surface in all seasons; indicative of topography controlled piston flow in a phreatic aquiferous formation.

The results of laboratory analysis of groundwater together with hydrogeochemical tools have elucidated the processes and mechanisms affecting the groundwater chemistry in Yaoundé: Chemical weathering of rock-forming minerals and atmospheric precipitation are the major and minor factors influencing the processes of groundwater ions acquisition from the matrix of the aquiferous formation while ion exchange, dissolution and mixing are the mechanisms by which the groundwater equilibrates and develops its chemical character over its flow domain. The dominant water types are Ca-rich waters and $M g$-rich waters. The dominant Hydrogeochemical facies are; $\mathrm{Ca}-\mathrm{Mg}-\mathrm{HCO}_{3}$ in the rainy season and $\mathrm{Ca}-\mathrm{Mg}-\mathrm{Cl}-\mathrm{SO}_{4}$ in the dry season. All samples are "fresh water" type during all seasons.

The $\mathrm{Ca}-\mathrm{Mg}-\mathrm{HCO}_{3}$ hydrogeochemical facies is characteristic of freshly recharged groundwater that has equilibrated with $\mathrm{CO}_{2}$ and soluble carbonate minerals under open system conditions in the vadose zone in a single hydraulic phreatic aquiferous fractured rock formation; the Yaoundé migmatite gneiss.

The Yaoundé groundwater samples in this fractured rock aquifer belong to the bicarbonate group with significant amounts of magnesium and calcium cations. The Sodium and Potassium content can be attributed to the presence of clays in the geology resulting in the release of potassium and sodium ions from the argillaceous materials by ion-exchange processes between the formation waters and clay minerals.

The overall chemical qualities of ground water with respect to drinking standards are good in all seasons with low TDS and are soft.

Quantitative chemical analysis results reflect the dominant anions to be calcium and Magnesium and the dominant anions bicarbonate and chloride characteristic of migmatite gneiss basement in Africa.

The $\mathrm{pH}$, electrical conductivity, total dissolved solids and temperature values of water samples are below guideline acceptable limits and variable with seasons indicative of phreatic aquifers (WHO, 2017).

RSC, SAR, SSP, MAR, PI and KR indicating the suitability of groundwater samples for irrigation is Excellent-to-Good in almost all cases. By these indices the groundwater quality of Yaoundé has been assessed for its agro-industrial suitability, found to neither cause salinity hazards nor have an adverse effect on the soil properties and is thus suitable for irrigational purposes. 


\section{Conclusion}

The process of ions acquisition of Yaoundé groundwater is three-fold: by recharge through atmospheric precipitation, by ion exchange/simple dissolution between the rock-groundwater and by groundwater mixing in its flow path.

The groundwater in Yaoundé is of $\mathrm{CaHCO}_{3}, \mathrm{MgHCO}_{3}$ and $\mathrm{MgCl}^{-}$freshwater types low in ionic content that vary with seasons and soft, typical of phreatic aquifers in basement aquifers.

Groundwater chemical quality indices indicate the water is good for domestic and agro industrial use in both seasons.

The Yaounde gneiss fractured rock aquifer is made up of three flow fields: a) The local flow field with stagnant areas where infiltrated water is almost stationary and connected to the other flow regimes only during the peak of the rainy season, with the dominant hydrogeochemical facies being $\mathrm{Ca}-\mathrm{Mg}-\mathrm{Cl}-\mathrm{SO}_{4}$ at all seasons; b) The intermediate flow field where some fissures are interconnected to other fissures in the meter scale during the dry season; and c) The regional flow field where the fissures are interconnected in the kilometer scale in all seasons. The dominant hydrogeochemical facies in the intermediate and regional flow is $\mathrm{Ca}-\mathrm{Mg}-\mathrm{HCO}_{3}$.

The weathered regolith, the local fissures and intermediate fissures/fractures and the regional fracture networks form a single chemically continuous unit indicating a single phreatic weathered basement fractured-rock aquifer of variable depth up to $83 \mathrm{~m}$.

There is a need for more detailed studies to determine aquifer characteristics: permeability, transmissivity and storativity, vertical and lateral regional extent of aquifer boundaries in this aquifer, groundwater pollution potentials for biological, organic and trace metals to enable a complete characterization of these aquiferous formations.

\section{Acknowledgements}

We sincerely thank all the field workers, Geofor-Cameroon and the private well owners for access and well data.

\section{Funding}

This research did not receive any specific grant from funding agencies in the public, commercial, or not-for-profit sectors.

\section{Conflicts of Interest}

None.

\section{References}

Acworth, R. I. (1987). The Development of Crystalline Basement Aquifers in Tropical Environment. Quarterly Journal of Engineering Geology, 20, 265-272. https://doi.org/10.1144/GSL.QJEG.1987.020.04.02 
American Public Health Association (APHA) (1995). Standard Methods for Examination of Water and Waste Water. Washington DC: American Public Health Association, American Water Works Association and Water Pollution Control Federation.

Asadi, J. J., Vuppala, P., \& Reddy, M. A. (2007). Remote Sensing and GIS Techniques for Evaluation of Groundwater Quality in Municipal Corporation of Hyderabad (Zone-V), India. International Journal of Environmental Research and Public Health, 4, 45-52. https://doi.org/10.3390/ijerph2007010008

Barcelona, M. J., Gibbs, J. P., Hellfrich, J. A., \& Garske, E. E. (1985). Practical Guide for Groundwater Sampling (p. 169). US Environmental Protection Agency, EPA/600/2-85/104.

Clark, L. (1985). Groundwater Abstraction from Basement Complex Areas of Africa. Quarterly Journal of Engineering Geology and Hydrogeology, 18, 25-34. https://doi.org/10.1144/GSL.QJEG.1985.018.01.05

Dewandel, B., Lachassagne, P., Maréchal, J. C., Wyns, R., \& Krishnamurthy, N. S. (2006). A Generalized 3-D Geological and Hydrogeological Conceptual model of Granite Aquifers Controlled by Single or Multiphase Weathering. Journal of Hydrology, 330, 260-284. https://doi.org/10.1016/j.jhydrol.2006.03.026

Djeuda Tchapnga, H. B., Tanawa, E., Temgoua, E., Siakeu, J., \& Ngo Massana, B. (1999). Flow Pattern, Recharge Mechanism and Residence Time of Groundwater in the Aquiferous Formations of the Weathered Basement: Case Study of the Anga'a Basin in Yaoundé, Cameroun (pp. 117-126). Yaoundé: University Press Yaoundé.

Doneen, L. D. (1962). The Influence of Crop and Soil on Percolating Water. In Proceedings 1961 Biennial Conference on Groundwater Recharge (pp. 156-163). Fresno, CA: Ground Water Recharge Laboratory, Southwest Branch, Soil and Water Conservation Research Division.

Doneen, L. D. (1964). Water Quality for Agriculture (p. 48). Davis, CA: University of California.

Durov, S. A. (1948). Classification of Natural Waters and Graphical Representation of Their Composition. Doklady Akademii Nauk SSSR, 59, 87-90.

Eaton, F. M. (1950). Significance of Carbonate in Irrigation Water. Soil Science, 69, 123-134. https://doi.org/10.1097/00010694-195002000-00004

Fouépé Takounjou, A. (2012). Groundwater Flow Modeling and Mass Transport Simulation in a Shallow Aquifer on Crystalline Basement: The Case of the Anga'a River Watershed, Yaoundé-Cameroon. Ph.D. Thesis, Cameroon: University of Yaoundé.

Fouepe Takounjou, A., Ndam Ngoupayou, J. R., Riotte, J., Takem, G. E., Mafany, G., Marechal, J. C., \& Ekodeck, G. E. (2011). Estimation of Groundwater Recharge of Shallow Aquifer on Humid Environment in Yaoundé-Cameroon Using Hybrid Water-Fluctuation and Hydrochemistry Methods. Environmental Earth Sciences, 64, 107-118. https://doi.org/10.1007/s12665-010-0822-x

Gibbs, R. J. (1970). Mechanisms Controlling World's Water Chemistry. Science, 170, 1088-1090. https://doi.org/10.1126/science.170.3962.1088

Giggenbach, W. F. (1988). Geothermal Solute Equilibria. Derivation of Na-K-Mg-Ca Geoindicators. Geochimica et Cosmochimica Acta, 52, 2749-2765. https://doi.org/10.1016/0016-7037(88)90143-3

Hem, J. D. (1985). Study and Interpretation of the Chemical Characteristics of Natural Water (3rd ed.). Jodhpur, Rajasthan: Scientific Publishers.

Hounslow, A. W. (1995). Water Quality Data: Analysis and Interpretation (p. 397). New York: Lewis Publishers.

ISO (2003). Standard ISO 5667 3: Water Quality_Sampling_Part 3: Guidance on the 
Preservation and Handling of Water Samples. Geneva: International Organization for Standardization.

ISO (2006). Standard ISO 5667 1: Water Quality-Sampling_Part 1: Guidance on the Design of Sampling Programs and Sampling Techniques. Geneva: International Organization for Standardization.

ISO (2009). Standard ISO 5667-11: Water Quality-Sampling-Part 11: Guidance on Sampling of Groundwaters. Geneva: International Organization for Standardization.

Kelley, W. P. (1940). Permissible Composition and Concentration of Irrigation Waters. Proceedings of the American Society of Civil Engineers, 66, 607-613.

Kelly, W. P. (1963). Use of Saline Irrigation Water. Soil Science, 95, 385-391. https://doi.org/10.1097/00010694-196306000-00003

Khodapanah, L., Sulaiman, W. N. A., \& Khodapanah, N. (2009). Groundwater Quality Assessment for Different Purposes in Eshtehard District Tehran, Iran. European Journal of Scientific Research, 36, 543-553.

Kringel, R., Rechenburg, A., Kuitcha, D., Fouépé, A., Bellenberg, S., Kengne, I. M., \& Fomo, M. A. (2016). Mass Balance of Nitrogen and Potassium in Urban Groundwater in Central Africa, Yaoundé Cameroon. Science of the Total Environment, 547, 382-395. https://doi.org/10.1016/j.scitotenv.2015.12.090

Kuitcha, D., Ndjama, J., Tita, A. M., Lienou, G., Kamgang, K. B. V., Ateba, B. H., \& Ekodeck, G. E. (2010). Bacterial Contamination of Water Points of the Upper Mfoundi Watershed, Yaoundé, Cameroon. African Journal of Microbiology Research, 4, 568-574.

Langguth, H. R. (1996). Groundwater Characteristics in Bereiech Des Velberter Sattles (p. 127). North Rhine-Westphalia: Ministry of Agricultural and Land Management Research Duesseldorf.

Lloyd, J. A., \& Heathcote, J. A. (1985). Natural Inorganic Hydrochemistry in Relation to Groundwater: An Introduction (p. 296). New York: Oxford University Press.

Mvondo, H., Owona, S., Ondoa, J. M., \& Essono, J. (2007). Tectonic Evolution of the Yaoundé Segment of the Neoproterozoic Central African Orogenic Belt in Southern Cameroon. Canadian Journal of Earth Sciences, 44, 433-444.

https://doi.org/10.1139/e06-107

Nola, M., Njine, T., Monkiedje, A., Sikati, F. V., Djuikom, E., \& Tailliez, R. (1998). Bacteriological Quality of Streams and Wells in Yaoundé, Cameroun. Cahier Santé, 8, 330-336

Nyende, J., Van Tonder, G. \& Vermeulen, D. (2014). Hydrochemical Characteristics of Ground and Surface Water under the Influence of Climate Variability in Pallisa District, Eastern Uganda. International Journal of Environmental Science and Toxicology Research, 2, 90-107.

Nzenti, J. P., Barbey, P., Macaudiere, J., \& Soba, D. (1988). Origin and Evolution of the Late Precambrian High-Grade Yaoundé Gneisses (Cameroon). Precambrian Research, 38, 91-109. https://doi.org/10.1016/0301-9268(88)90086-1

Obiefuna, G. I., \& Sheriff, A. (2011). Assessment of Shallow Ground Water Quality of PindigaGombe Area, Yola Area, NE, Nigeria for Irrigation and Domestic Purposes. Research Journal of Environmental and Earth Sciences, 3, 131-141.

Paliwal, K. V. (1972). Irrigation with Saline Water (p. 198). New Delhi: Indian Agricultural Research Institute.

Piper, A. M. (1944). A Graphic Procedure in the Geochemical Interpretation of Water Analysis. Eos, Transactions American Geophysical Union, 25, 914-928. 
https://doi.org/10.1029/TR025i006p00914

Pradhan, S. K., Patnaik, D., \& Rout, S. P. (1998). Ground Water Quality: An Assessment around a Phosphatic Fertilizer Plant at Paradip. Indian Journal Environment Protection, $18,769-772$.

Raghunath, I. I. M. (1987). Groundwater (2nd ed., pp. 344-369). New Delhi, India: Wiley Eastern Ltd.

Richards, L. A. (1954). Diagnosis and Improvement of Saline Alkali Soils. Agriculture Handbook 60. Washington DC: US Department of Agriculture.

Rossetto, R., De Filippis, G., Borsi, I., Foglia, L., Massimiliano, C., Criollo, R., \& Vázquez-Suñé, E. (2018). Integrating Free and Open Source Tools and Distributed Modelling Codes in GIS Environment for Data-Based Groundwater Management. Environmental Modelling and Software, 107, 210-230.

https://doi.org/10.1016/j.envsoft.2018.06.007

Shuttle Radar Topographic Mission, SRTM (NASA, Version 4) (2018). http://srtm.csi.cgiar.org

Sisodia, R., \& Moundiotiya, C. (2006). Assessment of the Water Quality Index of Wetland Kalakho Lake, Rajasthan, India. Journal of Hydro-Environment Research, 14, 1-11.

Szaboles, I., \& Darab, C. (1964). The Influence of Irrigation Water of High Sodium Carbonate Content of Soils. In Proceedings of 8th International Congress on International Society of Soil Science (pp. 803-812). Hungary: Research Institute for Soil Sciences and Agricultural Chemistry of the Hungarian Academy of Sciences.

Tabue, Y. J., Feumba, R., Wethe, J., Ekodeck, G. E., \& De Marsily, G. (2012). Evaluation of Groundwater Suitability for Domestic and Irrigational Purposes: A Case Study from Mingoa River Basin, Yaoundé, Cameroon. Journal of Water Resource and Protection, 4, 285-293. https://doi.org/10.4236/jwarp.2012.45031

Tanawa, E., Djeuda Tchapnga, H. B., Ngnikam, E., Temgoua, E., \& Siakeu, J. (2002). Habitat and Protection of Water Resources in Suburban Areas in African Cities. Building and Environment, 37, 269-275.

https://doi.org/10.1016/S0360-1323(01)00024-5

Teikeu, A. W., Njandjock, N. P., Bisso, D., Yene Atangana, Q., \& Sep Nlomgan, J. P. (2012). Hydrogeophysical Parameter Estimation for Aquifer Characterization in Hard Rock Environment: A Case Study from Yaoundé, Cameroon. Journal of Water Resource and Protection, 3, 244-253.

Teikeu, A. W., Njandjock, N. P., Tabod, C. T., Akame, J. M., \& Nshagali, G. B. (2016). Hydrogeological Activity of Lineaments in Yaoundé Cameroon Region Using Remote Sensing and GIS Techniques. The Egyptian Journal of Remote Sensing and Space Sciences, 19, 49-60. https://doi.org/10.1016/j.ejrs.2015.12.006

Todd, D. K. (1980). Ground Water Hydrogeology. New York: John Wiley and Sons, Inc.

United States Central Intelligence Agency (2018). World Facts Book. https://www.cia.gov

Wilcox, L. V. (1955). Classification and Use of Irrigation Waters (p. 19). Circular No. 960, Washington DC: United States Department of Agriculture.

World Health Organization, WHO (2017). Guidelines for Drinking-Water Quality: 4th Edition, Incorporating the 1st Addendum. Geneva: World Health Organization.

Wyns, R. J., M., Lachassagne, P., Baltassat, J.-M., Vairon, J., Legchenko, A., \& Mathieu, F. (2004). Application of SNMR Soundings for Groundwater Reserves Mapping in Weathered Basement Rocks (Brittany France). Bulletin of the Geology Society of France, 175, 21-34. https://doi.org/10.2113/175.1.21 